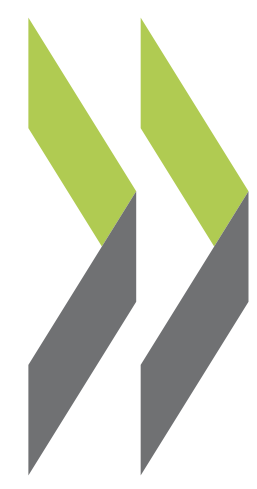

OECD Economics Department Working Papers No. 280

\section{Contributions of Financial Systems to Growth in OECD} Countries

\author{
Michael Leahy, \\ Sebastian Schich, \\ Gert Wehinger, \\ Florian Pelgrin,
}

Thorsteinn Thorgeirsson 
Organisation de Coopération et de Développement Economiques

Organisation for Economic Co-operation and Development

21-Mar-2001

ECONOMICS DEPARTMENT

English text only

Cancels \& replaces the same document of 26 January 2001

CONTRIBUTIONS OF FINANCIAL SYSTEMS TO GROWTH IN OECD COUNTRIES

ECONOMICS DEPARTMENT WORKING PAPERS No. 280

by

Michael Leahy, Sebastian Schich, Gert Wehinger, Florian Pelgrin and Thorsteinn Thorgeirsson

Most Economics Department Working Papers beginning with No. 144 are now available through OECD's Internet Web site at http://www.oecd.org/eco/eco/ 


\begin{abstract}
RÉSUMÉ
The recent period of sustained high growth in the United States has drawn attention to its financial system and the efficiency with which it seems to be able to channel funds to new productive investment projects, particularly in hi-tech industries. This study examines the role played by the financial systems in OECD countries and how they affect resource allocation and growth. It provides evidence suggesting that legal and regulatory framework conditions for financial systems, and particularly their enforcement and transparency, support innovation and investment in new enterprises. In addition, using dynamic panel regression techniques, the study finds significant relationships between investment and financial development, as measured by indicators of the scale of financial activity. Evidence is also found of significant relationships between financial development and growth — over and above the links via investment — indicating impacts via overall economic efficiency.
\end{abstract}

JEL classification: C21, C23, E22, G20, G30, O40.

Keywords: growth, development, innovation, investment, financial system, shareholders, creditors, enforcement, transparency, panel analysis.

$* * * * * *$

La forte croissance soutenue aux États-Unis pendant la période récente a attiré l'attention sur son système financier et l'efficacité avec laquelle il semble être capable de financer des nouveaux projets d'investissement productif, en particulier dans les industries de haute technologie. Cette étude examine le rôle joué par les systèmes financiers dans les pays de l'OCDE et comment ils influent sur l'allocation des ressources et la croissance. Elle prouve à l'évidence que les systèmes financiers réunissant les conditions d'un cadre institutionnel et réglementaire, en particulier dans l'exécution et la transparence, contribuent à l'innovation et l'investissement dans de nouvelles entreprises. De plus, en utilisant des techniques de régression dynamique en panel, l'étude constate des relations significatives entre l'investissement et le développement financier, qui servent d'indicateurs de l'échelle de l'activité financière. Il parait tout aussi évident qu'il y a une relation entre le développement financier et la croissance -- en outre et d'ailleurs par le biais de l'investissement -- avec des répercussions sur l'ensemble de l'efficience économique.

Classification JEL : C21, C23, E22, G20, G30, O40.

Mots-clés : croissance, développement, innovation, investissement, système financier, actionnaires, créanciers, recouvrement, transparence, analyse par panel.

Copyright: OECD 2001

Applications for permission to reproduce or translate all, or part of, this material should be made to: Head of Publications Service, OECD, 2 rue André-Pascal, 75775 PARIS CEDEX 16, France. 


\section{TABLE OF CONTENTS}

1. Introduction

2. Financial system development and growth: theory 5

$2.1 \quad$ Services provided by financial systems

2.2 Financial framework conditions

3. Empirical links between framework conditions and innovation, investment and growth _ 7

$3.1 \quad$ Indicators of innovation 8

$3.2 \quad$ Financial framework conditions

3.3 Empirical relationship between financial framework conditions and innovation $\ldots 12$

4. Empirical relationship between financial system development and investment and growth _...........14

4.1 Indicators of financial development and investment $\ldots$

4.2 Financial development and investment levels 17

4.3 Financial development and growth $\quad 21$

5. Summary and assessment $\quad 22$

Box. Robustness of results 19

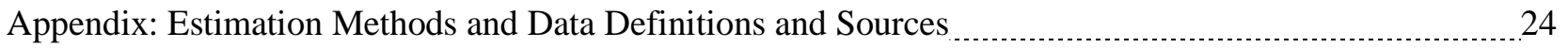

Bibliography

Tables and Figures 36 


\title{
CONTRIBUTIONS OF FINANCIAL SYSTEMS TO GROWTH IN OECD COUNTRIES
}

\author{
Michael Leahy, Sebastian Schich, Gert Wehinger, Florian Pelgrin and Thorsteinn Thorgeirsson ${ }^{1}$
}

\section{Introduction}

1. The recent period of sustained high growth in the United States has drawn attention to its financial system and the efficiency with which it seems to be able to channel funds to new productive investment projects, particularly in high-tech industries. Questions have arisen as to what role the financial system has played in this recent episode; whether other countries' financial systems can and do play similar roles; and, more generally, whether financial structures have an impact on resource allocation and growth.

2. As a part of the OECD project on economic growth, we examine the role of financial systems in OECD countries. This paper provides evidence suggesting that financial system characteristics are linked to growth patterns in OECD countries. As with most studies of this nature, questions remain regarding the direction of causation in these relationships. Nonetheless, results from this study suggest:

- Legal and regulatory framework conditions for financial systems, and particularly their enforcement and transparency, support innovation and investment in new enterprises. However, evidence that framework conditions have a direct impact on investment and growth more broadly could not be identified with the data and methods used here.

- There are significant relationships in OECD countries between investment and financial development, as measured by indicators of the scale of financial activity. Evidence is also found of significant relationships between financial development and growth -- over and above the links via investment -- indicating impacts via overall economic efficiency.

3. In the next section the theoretical links between finance and growth are presented. The section focuses in turn on the services provided by financial systems that affect growth and the framework conditions for financial systems that shape relationships between firms and investors. In Section 3, empirical links between financial framework conditions and growth are examined, largely through their effects on innovation. Several indicators of innovative activity in OECD countries are presented and they are related to financial framework conditions through compound measures of investor protections constructed from a variety of indexes of shareholder and creditor rights, as well as indicators of enforcement and transparency. In Section 4, links between financial system development and investment and growth are examined using empirical methods designed to identify long-run relationships. Section 5 presents some concluding remarks.

1. The authors, all members of the Money and Finance Division in the Department of Economics, wish to thank, without implicating, Alain De Serres, Jørgen Elmeskov, Mike Feiner, Johannes Hoffmann, Mike Kennedy, Dirk Pilat and Ignazio Visco for helpful comments and suggestions. We are grateful also to Andrea Bassanini, Phil Hemmings and Stefano Scarpetta, with whom we collaborated on this project, for their comments, suggestions and inputs. Thanks are also due to Catherine Lemoine and Laure Meuro for statistical assistance and to Paula Simonin, Sarah Kennedy and Muriel Duluc for secretarial assistance. The views expressed in this Working Paper are those of the authors and are not necessarily shared by the OECD. 


\section{Financial system development and growth: theory}

4. This section first discusses the services provided by financial systems that influence innovation, investment and growth. Subsequently, some key financial framework conditions are examined, with a focus on how they affect the provision of financial services.

\subsection{Services provided by financial systems}

5. Outside of population increases, the driving forces behind sustained economic growth in most macro-economic growth theories, including neo-classical and endogenous growth theories, are technological change and capital accumulation. ${ }^{2}$ Financial systems play a role in the growth process because they are integral to the provision of funding for capital accumulation and for the diffusion of new technologies. The micro-economic rationale for financial systems is based largely on the existence of frictions in the trading system. In a world in which writing, issuing and enforcing contracts consume resources and in which information is not symmetric and its acquisition costly, properly functioning financial systems can reduce these information and transactions costs. In the process, savers and investors are brought together more efficiently and, ultimately, economic growth is affected. Financial systems perform several functions that serve to ameliorate these frictional costs (Pagano, 1993; Levine, 1997) and thus bear on capital accumulation and technological progress. Four broad groups of services are examined here: a) mobilising savings; b) diversifying risk; c) allocating savings; and d) monitoring the allocations of managers.

\subsubsection{Mobilising savings}

6. An important function of financial systems is that of mobilising savings. Without the pooling of the savings of individuals through financial intermediaries or through securities markets, the scale of investment projects is more likely to be constrained below what might be efficient. A well-developed financial system attracts and collects the small-denomination savings of individuals, so that profitable large-scale investments can be funded, thus potentially raising the overall level and possibly the efficiency of investment.

\subsubsection{Diversifying risk}

7. Financial systems provide insurance to individual savers against the idiosyncratic risk that a single investment pays no return and the liquidity risk that savers may need to withdraw investments before returns are available. As a result, high-return projects with long gestation periods or high but diversifiable risk are more likely to be funded. These diversification services are provided in part through the unbundling and pricing of risk, which leads to a better allocation of individual risks. In turn, growth and investment may be enhanced through the development of higher-return investment projects. On the other hand, it is possible that the lower risks and higher returns may prompt wealth holders to save less, if income effects dominate substitution effects, leading to reduced capital accumulation overall and the possibility of slower growth. ${ }^{3}$

\section{As used here, capital accumulation includes both physical and human capital.}

3. Even in the case where growth slows, however, improved opportunities for risk diversification should provide welfare gains. 


\subsubsection{Allocating savings to new projects}

8. For individual savers, the costs of acquiring and evaluating information on prospective projects can be high, making it more likely that worthy projects go without funding. Financial intermediaries that specialise in acquiring and evaluating information on prospective investment projects enable small investors, for a nominal fee, to locate higher return investments (Greenwood and Jovanovic, 1990). The improved allocation of savings among investment projects should enhance growth prospects. This efficiency gain may also translate into ongoing increases in the rate of growth if (specialised) intermediaries are more likely to discover those entrepreneurs who can successfully develop new technologies.

9. The role of securities markets in improving the allocation of savings to investment projects is less clear than that of financial intermediaries. On the one hand, deep and liquid securities markets provide incentives for individuals to seek information on investment opportunities, because information not already discounted into asset prices can provide profit opportunities for individuals who uncover it. On the other hand, securities prices may adjust so rapidly to new information that profit opportunities from information acquisition become limited, reducing the incentive to incur such retrieval costs in the first place. If the latter effect is dominant, well-developed securities markets may actually inhibit the allocation of resources to information acquisition (Stiglitz, 1985) and, as a consequence, diminish growth.

\subsubsection{Monitoring the allocations of managers}

10. Financial systems also serve in the monitoring of investments to reduce the risk that resources are mismanaged. The establishment of financial intermediaries that can monitor investments for groups of savers/investors reduces the duplication of monitoring costs that would be incurred if the savers conducted their own monitoring individually. Growing (functional and regional) specialisation of banks can reduce the cost of monitoring and, hence, that of financial intermediation (Harrison, Sussman and Zeira, 1999), although the question remains as to who is monitoring the monitors. Securities markets may act as a market for control and thereby function as a disciplining device that reduces agency costs. ${ }^{4}$ If concerns about mismanagement risk can be mitigated, a greater range of profitable investments may be funded and growth increased.

\subsection{Financial framework conditions}

11. The way in which financial systems perform these services depends in part on framework conditions - including the debtor, creditor and shareholder rights set out in bankruptcy codes, company laws and commercial codes. These rights provide the framework for the relationships between managers of a firm and holders of claims on the firm (in the form of debt or equity) as well as between different holders of claims. Other types of framework conditions, such as financial market regulations, are also relevant, although these are not explicitly considered in this paper. The same holds for implicit or explicit rules governing relations with other stakeholders.

4. The design of financial contracts to encourage managers to run firms and projects in the interests of creditors and shareholders -- for example, by linking their compensation to equity performance -- can also reduce the need for monitoring. However, empirical studies of such compensation plans have raised concerns about the efficiency of these contracts which may not be well-priced due to asymmetric information (Maher and Andersson, 2000). 
12. Shareholder rights that result in ownership concentration may serve to obviate the agency problem by helping shareholders internalise the costs of monitoring, but these rights may also result in less liquid equity markets that provide fewer opportunities for risk diversification and greater obstacles to funding risky projects. In addition, when some shareholders have a controlling influence, conflicts can arise between the weaker owners and the controlling bloc of shareholders, who may attempt to extract private benefits. The possibility of such conflicts can reduce incentives to invest in shares and the role of the stock market in mobilising saving. On the other hand, framework conditions with strong protections for minority owners may facilitate liquid equity markets and greater opportunities for diversification but at the same time leave owners with only weak incentives to monitor their investments.

13. Creditor rights and bankruptcy provisions offer similar trade-offs. On the one hand, a harsher bankruptcy policy might elicit more efficient decision-making by managers, who have an incentive to preserve their jobs, which by itself would promote higher levels of output and optimal growth. ${ }^{5}$ On the other hand, strong creditor rights may reduce incentives for managers to undertake higher-risk projects that also offer the potential for higher future returns and this could lead to less innovation and slower long-run growth.

14. Secured creditor rights are likely to be somewhat ambiguous in terms of their effects on investment. Stronger secured creditor rights may lower the cost of collateralised borrowing, but they likely raise the costs of non-secured borrowing and issuing equity, since creditors with lower priority and shareholders must accept what is left after secured creditors take their compensation. ${ }^{6}$ This effect can be tempered, however, if diversification opportunities are as available for creditors as they are for shareholders, so that idiosyncratic firm risk can be eliminated with proper portfolio management.

\section{Empirical links between framework conditions and innovation, investment and growth}

15. Given the trade-offs involved, questions of how financial framework conditions affect innovation, investment and growth are essentially empirical. However, the complex nature of both evolving financial systems and their interactions with the growth process, makes empirical analysis difficult. Furthermore, because alternative features of financial systems are likely to be important at different times, stable links between specific features and economic growth may be difficult to identify. In principle, it would be desirable to measure directly the efficiency with which financial systems provide the services that influence growth and to link the provision of these services backwards to financial market framework conditions and forwards to investment and growth. However, data on financial sector activities do not match with particular service functions.

5. Some might argue that a risk-averse manager might work harder if the variability of his or her income were reduced, which would imply that a more lenient bankruptcy law would result in more effort.

6. Senior secured creditors have a claim on collateral; their interest would be to repossess the collateral and either liquidate or keep it. Repossession of assets that are central to the operation of the firm typically forces the liquidation of the firm. Senior secured creditors would generally have no interest in reorganisation, which might force them to accept a smaller percentage of the value of their claims, or at a minimum delay their access to the firm's assets. After more senior creditors have been paid, however, it is not always clear that the remaining value in the firm will be sufficient to meet the remaining claims. Thus, more junior creditors, particularly unsecured ones, and shareholders may be inclined to seek reorganisation in hopes that they will get more of their money back if the firm is able to recover. Governments, suppliers, customers and employees, who typically have no direct role in the liquidation process, are also likely to prefer reorganisation to quick liquidation because they may have an interest in continuing their relationships with the distressed firm. 
16. Against this background, this section of the paper explores the empirical relationships directly between framework conditions and measures of innovation, investment and growth. The parts of the section deal in turn with indicators of innovation and financial framework conditions and with uncovering empirical relationships between the two sets of indicators. These sub-sections also look briefly at the relationship between the framework conditions and investment and growth.

\subsection{Indicators of innovation}

17. While measures of innovative activity are improving, problems still exist. Innovation relates to the introduction of new products, processes and organisational structure. ${ }^{7}$ It differs from technological change, since it also includes non-technological changes (which are particularly important in the service sector) and since technological change also incorporates the diffusion of existing technologies. Measures of the results of innovative activity are flawed due, not least, to significant omissions in coverage, inconsistencies across countries, and failures to characterise the value of the innovation. Measures of the resources going into innovative activity are also problematic. As input measures, they are not designed to measure innovation as an output. They may also neglect certain innovative practices altogether. Because these difficulties would render any one indicator unreliable, a number of measures are considered.

- Measures of productivity, either labour productivity or multi-factor, are clearly related to innovation and growth, but the standard versions of these measures do not capture precisely the role of innovative activity in an economy. Labour productivity is likely to overstate the contribution of innovation because it can be boosted by pure capital deepening without any contribution from innovation (Scarpetta et al. 2000). A pure multi-factor productivity (MFP) measure does not suffer from this weakness but is likely to understate the rate of innovation when embodied technical progress is recorded as an expansion of the capital stock. This happens, for example, with hedonic adjustment to investment, which feeds through to capital stocks. $^{8}$

- Data on patent applications also provide a measure of the results from certain types of innovative activity. They do not, however, measure the innovation content of patented products and services. In fact, many patents are trivial, and some may even be created as a business strategy to propagate misinformation that could distract competitors. As well, the propensity to take out patents has varied over time, inter alia, reflecting changing views on what can be patented and on the desirability of widespread patenting. ${ }^{9}$

- Spending on research and development $(\mathrm{R} \& \mathrm{D})$ can be used as a measure of the inputs to a process whose objective is innovation. ${ }^{10}$ Since not all research is productive, this measure may overstate the innovation actually produced. On the other hand, not all innovations arise from designated research and development. There may well be unmeasured time and

7. See OECD's Oslo Manual (OECD/Eurostat, 1997) for an internationally accepted definition of innovation.

8. See Bassanini, Scarpetta and Visco (2000) for a fuller discussion of the role of embodied technological change in measured MFP.

9. In addition, with national patent data, there may be significant cross-country differences in the number of patents registered because the cost of obtaining and maintaining patents varies among countries (OECD, 1998e). Cross-country data on patents granted in a single place under uniform conditions, such as in the United States or in Europe, would obviate that problem, although the resulting patent shares may show a bias towards the home location and its major trading partners.

10. See Bassanini, Scarpetta and Hemmings (2001), which finds an influence from R\&D spending on growth. 
resources consumed by individuals whose primary occupation is not research, who nonetheless develop innovative procedures or products. Data on spending on R\&D will fail to capture this type of innovative activity. The number of researchers employed in R\&D activities provides a similarly imperfect measure of inputs to the process of innovation.

- Because venture capital firms specialise in finding and developing new businesses, measures of venture capital investment can be seen as imperfect proxies for investment in innovative new businesses. While such measures are clearly incomplete, they nonetheless offer another reading on innovative activity. In addition, venture capital firms typically use equity markets and, in particular, initial public offerings (IPOs), to pass along investments that have matured, allowing them to re-liquefy their assets and seek new investment opportunities in new firms. Thus, a measure of IPO activity can also provide a reading on the degree of innovation associated with a given financial system.

\subsection{Financial framework conditions}

18. Several indicators of shareholder and creditor rights, of the enforcement of these rights and of the transparency of business accounting systems were reduced through principal component analysis to a single synthetic summary measure, referred to as the "compound measure" of investor protection (Table 1). ${ }^{11}$ Measures of investor protection for selected sub-groups of indicators were also calculated. To correspond to the data on innovation and growth in the 1990s, all these measures of investor protection are based on assessments of framework conditions as they were in the mid-1990s, not as they are today. In many cases, framework conditions have evolved since then, particularly regarding shareholder rights. ${ }^{12}$ The measures are designed to extract the common assessments from the various indicators, giving little weight to assessments idiosyncratic to each source. They are centred on zero and re-scaled to have a unit variance. A higher score for the investor protection measure is associated with generally stronger investor protections for the group of indicators.

19. In the next subsections, summaries are provided of the types of indicators for shareholder and creditor rights used in the analysis and of how these rights might effect the incentives of managers to operate firms efficiently. A similar summary is presented of the indicators of enforcement and transparency. As will be seen, the latter group of indicators appears to be more strongly associated with innovation and MFP growth.

\section{Shareholder rights}

20. Voting procedures play a key role in the exercise of shareholder rights. By voting for directors and on major corporate issues, shareholders can exercise their rights and influence company performance.

11. Details on the definitions and sources of these indicators are available in the appendix.

12. Framework conditions pertaining to the strength of shareholder rights appear to be in a state of flux in a number of OECD countries. Governments have introduced legislation to reform company law and regulatory bodies are changing codes, while stock exchanges and other securities organisations have introduced recommendations for the adoption of best practices regarding shareholder rights or created advisory panels to recommend reforms. Some of the reforms are still in process, others are voluntary, and still others are now binding. See OECD (2001). 
- The voting power of shareholders is redistributed with the issuance of non-voting shares or with the issuance of shares that have diluted or enhanced voting powers. ${ }^{13}$ Such redistribution is prohibited when legislation concerning shareholder rights requires that ordinary shares offer the equivalent of one vote per share. While one-share/one-vote provides the basis for an alignment of management incentives with the interests of shareholders, it does not preclude high ownership concentration, and the possibility of majority ownership blocs. ${ }^{14}$

- Some voting provisions can result in a distortion of the voting mechanism in favour of managers or of dominant shareholders at the expense of minority shareholders. This is the case where provisions raise the cost of voting, so that fewer shareholders will choose to exercise their rights to vote. One example is the prohibition on mailing a proxy vote. ${ }^{15}$ Another is a requirement that shareholders intending to vote in a shareholder meeting deposit their shares with the company or with a designated financial intermediary several days prior to the meeting. ${ }^{16}$

- Features supportive of minority shareholder representation include the possibility of cumulative voting, in which shareholders are permitted to cast all their votes for one candidate, or of proportional representation on the board. Either of these mechanisms allows minority shareholders to name a proportional number of directors.

- Minority shareholders (defined as those who own 10 per cent or less of capital) are sometimes given additional legal rights, such as the right to challenge managers' decisions in court. Courts would presumably find in favour of these "oppressed" minority shareholders if it were determined that their interests had not been fairly represented in the voting process.

- Providing existing shareholders the option to be first-in-line to purchase new issues of stock is seen as a defensive measure that prevents dilution of the voting power of existing shareholders, which might come about by issuing shares to favoured investors at belowmarket prices.

- Minority rights are more fully protected when it is possible to call a shareholder meeting at the request of shareholders controlling only a relatively small share of capital.

13. In France, there are shares whose voting power increases the longer they are held (OECD, 1997b; p. 115).

14. In the case of Germany, some of these conditions are expected to change. With the exception of Volkswagen, which has been granted an individual exemption, shares with multiple voting rights are due to be repealed in three years, and upper limits on voting rights will be abolished for listed companies (OECD, $1998 a$ ).

15. Annual shareholder meetings in Japan are concentrated on a single day in late June, and voting by mail is not allowed for some shareholders (La Porta, et al., 1998, p. 1127). For a discussion of recent reforms of corporate governance in Japan, see OECD (2001).

16. In many countries these conditions have changed recently. In Italy, the Testo Unico della Finanza (Consolidated Law of Financial Intermediation), which was approved in 1998, introduced -- among many other reforms -- voting by mail. In Germany, the Ministry of Justice endorsed in 1999 legislation to introduce electronic and postal voting. In addition, the German government has recommended the adoption of US-style record dates, arguing that the current rule, which requires owners to deposit shares in order to vote, discourages voting at shareholder meetings. In the Netherlands, the government declared in 1999 that mail ballots are allowed under the law, provided the owners are fully identified. In addition, the government announced its commitment to introduce record dates (seven days before a shareholders' meeting) so that proxy-processing companies will be able to confirm that the proxies submitted were from their true owners. In 1999, Portugal amended its Securities Code to allow for postal and proxy voting. 


\section{Creditor rights}

21. Creditor rights and bankruptcy provisions can also affect the incentives of managers and the incentives of lenders to provide funding.

- Reorganisation procedures that impose an automatic stay on assets, preventing secured creditors from getting possession of their collateral, will deter immediate liquidation of the firm. Such provisions protect the interests of managers, other creditors, shareholders and stakeholders at the expense of secured creditors. ${ }^{17}$

- In some countries, secured creditors retain their priority when creditors get paid. Elsewhere, however, secured creditors are not necessarily paid first during a reorganisation, but after other stakeholders, such as the government and employees.

- The absence of restrictions on initiating bankruptcy filings can put secured creditors at a disadvantage. When bankruptcy filings can be initiated by management, as they typically are in the United States, or more generally entered into without restrictions, such as the consent of creditors, it becomes more difficult for creditors to liquidate the firm. Such provisions are typically protective of management. ${ }^{18}$

- When managers must be replaced under reorganisation, bankruptcy codes provide a clear signal to managers about the consequences of default. In other cases, however, when management is not necessarily dismissed during reorganisation, the signal is less clear. Continuing employment is not guaranteed, however, and even when it is, and the degree of authority retained by managers may be curtailed severely. ${ }^{19}$

17. In some cases, determining the creditor protection of bankruptcy laws on the automatic stay is complicated. For example, in the United States, the automatic stay applies in Chapter 11 bankruptcies, however, secured creditors must be given compensating protection (White, 1996). UK bankruptcy law offers no stay on assets under receivership, the procedure used most frequently, although secured creditors do face a stay under the administration order procedure.

18. Incentives for management to initiate bankruptcy filings are strong in the United States, where creditors bear the burden of proving that the firm is in default. While in many European countries the burden of proof is on managers to show that the firm is not in default, reducing incentives for management to initiate bankruptcy proceedings, there are penalties for managers and even firms' banks in some cases for delaying filing (White, 1996).

19. In the United States, managers typically keep control of the firm during Chapter 11 proceedings, with the bankruptcy court providing only limited surveillance. In France, an outside bankruptcy official is appointed to monitor the operations of the firm for a mandatory period to determine whether reorganisation is appropriate and, if so, to formulate a plan. During this period, the court can order that managers remain in control under the supervision of the outside official, or the court can order that the managers be replaced. (Because the official is a representative of the state, not creditors, creditors in France have only limited influence on the reorganisation process.) In Germany, management can, in principle, stay on during reorganisation, but the reorganisation procedure is rarely used because the absence of an automatic stay for secured creditors tends to undermine the feasibility of any reorganisation proceedings. Without the stay, secured creditors have no incentive to agree to a reorganisation plan in which they would receive only a percentage of the value of their collateral. This feature may also explain why firms have so little unsecured debt in Germany. Thus, the possibility that management could stay on during reorganisation provides them very little protection in this case. The new bankruptcy law in Germany is more attractive to failing firms, in part because it effectively includes an automatic stay against secured creditors. 


\section{Enforcement and transparency}

22. Debtor, creditor and shareholder rights are of little consequence without enforcement and disclosure. Perceptions that contracts will be enforced and that accurate information on performance will be disseminated in a timely manner are important aspects of the framework conditions for financial systems, which can have a strong influence on the willingness of savers and investors to enter into contractual agreements. Indicators in this area often have a subjective character and should be interpreted cautiously. ${ }^{20}$ Several indicators of these types of framework conditions are considered (Table 2).

- The first two indicators aim to provide general impressions of the degree to which rules and regulations are observed. The two sources used describe these ratings as attempts to assess the "law and order tradition" 21 of a country and the "respect of citizens . . . for the rules that govern their interactions". ${ }^{22}$

- The indicator of judicial system efficiency tries to assess the "efficiency and integrity of the legal environment as it affects business, particularly foreign firms".

- The policy effectiveness indicator attempts to characterise the ability of a government to formulate and implement sound policies. This measure synthesises a number of features, including perceptions of a government's ability to carry out stated programmes, the independence of the civil service from political influence, and the predictability of changes in rules and laws.

- The risk of contract repudiation is an assessment of the "risk of a modification in a contract taking the form of a repudiation, postponement or scaling down" due to social, economic or political pressures.

- The rating on accounting standards is an index created by examining companies' annual reports for the inclusion or omission of 90 items. Reports that comply with accounting standards enhance the ability of investors to understand and evaluate company decisions. Furthermore, some legal remedies for investors require evidence from the firm's accounts on its conduct or performance.

\subsection{Empirical relationship between financial framework conditions and innovation}

23. The compound measure of investor protection is used to estimate bi-variate relationships between financial framework conditions and various indicators of innovation, investment and growth. Other investor protection measures, derived from the first principal component of subsets of the financial framework conditions, are also used. More detailed analysis, using additional explanatory variables, is possible (and was conducted), but the relationships become more difficult to identify with any degree of confidence as degrees of freedom decline. Degrees of freedom are limited because the indicators of

20. All of these indicators are taken from sources outside the OECD and none should be interpreted as an assessment by the OECD.

21. La Porta et al. (1998).

22. Kaufmann et al. (1999b). 
financial framework conditions lack a time dimension, which restricts the analysis to the cross-country (cross-section) dimension. ${ }^{23}$

24. Several measures of innovation appear to be positively correlated with the compound measure of investor protection.

- R\&D spending, R\&D employment and patent applications in OECD countries tend to rise with investor protections (Figure 1 and Table 3). An alternative data set on patents granted in the United States, which eliminates some of the lack of comparability found in the national patent data, yields a similar relationship. ${ }^{24}$

- Measures of IPOs and venture capital investment, which can be seen as proxies for investment in innovative new businesses, have significant, positive correlations with the compound measure of investor protection (Figure 2 and Table 3).

25. Broad macroeconomic indicators show mixed results. The level of GDP, which may be indicative of the degree of use of best-practice technologies, is significantly higher in countries with a high score on the overall measure of financial framework conditions (Table 3). This relationship is, however, likely to involve complex causal patterns running in both directions. In contrast, no significant correlation could be found between investor protection and indicators of output growth, investment, and productivity growth. While it is possible that investor protections are not important in the determination of these variables, it is also possible that other factors not controlled for in this simple analysis make it difficult to detect the effects of investor protections. ${ }^{25}$ Finally, on the view that stronger investor protections might enable economies to adapt to and deploy changing technologies, reallocating resources to new activities more efficiently, the relationship between the change in MFP growth rates and the measure of investor protections was examined. The results indicate that cross-country changes in MFP growth from the 1980s to the 1990s are significantly correlated with the compound measure of investor protection used here, comparable to other results. ${ }^{26}$

26. Examination of the less aggregated measures of investor protection reveals that the enforcement and transparency indicators play a strong role in the bi-variate relationships (Table 3). With a measure of financial framework conditions that incorporates only the enforcement and transparency indicators, the significance of the correlations discussed above remains little changed. With measures of shareholder and creditor rights only, however, these correlations become largely insignificant. This result is consistent with a number of hypotheses, including:

23. Twenty-one OECD countries were included: Australia, Austria, Belgium, Canada, Denmark, Finland, France, Germany, Greece, Ireland, Italy, Japan, Netherlands, New Zealand, Norway, Portugal, Spain, Sweden, Switzerland, the United Kingdom, and the United States. Some OECD countries were not included in the analysis of this section, owing to the developing nature of their financial systems and missing data.

24. Data source is US Department of Commerce, Patent and Trademark Office.

25. In particular, as regards the growth of multi-factor productivity, national productivity gains due to so-called "catch-up" or convergence effects may be masking the effects of framework conditions on "new" innovation. However, the distinction between genuine innovation and catch-up is obscured for a number of reasons. While innovation may be more important when a country is at the technological frontier, it is unlikely that any country is at the frontier in every industry or technology. Furthermore, catch-up may require innovation to the extent that local conditions must be adapted to make them suitable for frontier technologies.

26. See Bassanini, Scarpetta and Visco (2000) and Bassanini, Scarpetta and Hemmings (2001). 
- The data may be measuring shareholder and creditor rights accurately, but the variation in those conditions across OECD countries is not sufficient to generate statistically significant relationships. There may be more variation in the enforcement indicators.

- The data may be measuring shareholder and creditor rights accurately and there may be significant variation in those rights across OECD countries. However, these data may be too rich to be described reasonably by only one principal component. ${ }^{27}$ Nonetheless, experimentation with more factors did not improve the significance of the investor protection measure.

- Shareholder and creditor rights in OECD countries may not be as important for innovation (or for investment and growth) as enforcement and transparency. It is possible that financial systems tend to adapt to whatever legal framework conditions are in place, so as to overcome the frictions and information asymmetries that can discourage investment and saving. When enforcement and transparency are strong, it may be easier for financial systems to make the adjustments necessary to provide the services required to facilitate saving and investing. In such an environment, the particular rights and mechanisms that apply may be less critical to the functioning of economic activity than their clear and consistent enforcement and execution.

27. The empirical tools used here, with their focus on framework conditions, undoubtedly fail to incorporate many of the important features of the economic relationships between savers and investors. Nonetheless, they seem to provide some tentative evidence that financial framework conditions have a role to play in the process of innovation and perhaps growth. The next section examines indicators of the development of financial systems, which include a time dimension and therefore permit the use of analytical methods that control for multiple factors affecting aggregate measures of investment and growth.

\section{Empirical relationship between financial system development and investment and growth}

28. Most empirical studies of the determinants of growth in a broad sample of countries conclude that financial development provides a significant contribution to growth (e.g. Levine, 1997; Levine, Loayza and Beck, 2000; Temple, 1999). Drawing lessons for OECD countries from these studies is difficult, however, as strong results are obtained only when low and middle income economies are included in the sample (De Gregorio and Guidotti, 1995). Studies focused on OECD countries have typically failed to find significant links between financial development and growth (Andrés, Hernando and López-Salido, 1999; King and Levine, 1993). Using methods similar to those of earlier studies of growth for broad samples of countries, we also found no evidence that financial development contributes significantly to growth in OECD countries.

29. Various interpretations have been offered for the failure to find a finance-growth link in the OECD-only sample, including:

- Close international linkages across OECD financial markets make it difficult to identify the influence of domestic financial development on a country's growth rate.

27. For the compound measure of investor protection (including shareholder and creditor rights as well as data on enforcement and transparency), up to six principal components would be justified using the Kaiser criterion, which includes factors with an eigenvalue above one. For shareholder and creditor rights only, up to four principal components would be justified, while only one principal component captures the bulk of the variation in the data on enforcement and transparency. 
- OECD countries are at a more advanced stage of development, where financial systems may have a different (and more difficult to measure) impact on growth than in earlier stages of development.

- Cross-country econometric methods may not be suited to detect these different channels. If financial development and its effects on growth in OECD countries varies over time as well as across countries, methods that ignore the information provided by the time variation may have difficulty identifying longer-run cross-country relationships.

30. This section takes forward earlier analysis of the finance-growth link for OECD countries, bearing in mind these problems. The new analysis identifies two significant channels. First, financial development appears to be related to economic growth through its relationship with fixed investment. In Bassanini, Scarpetta and Hemmings (2001), the authors have confirmed that investment plays an important role in the process of economic growth. In both that and the present paper, a link between financial development and fixed investment is found. ${ }^{28}$ Different indicators of financial development are used. The results appear to be strongest and most robust for stock market capitalisation and somewhat weaker, though still significant, for private credit of deposit money banks. Second, measures of financial development are significant in growth equations for OECD countries, even after controlling for the level of investment. Thus, other channels as well appear to link financial system development and economic activity.

31. The rest of this section first describes the proxy measures for financial development and the investment data. It then uses two different approaches to identify a relationship between financial system development and investment. The final part looks briefly at the other channels linking financial development and growth.

\subsection{Indicators of financial development and investment}

32. Measuring the services provided by a financial system is difficult. While a range of indicators is available, ${ }^{29}$ none is widely accepted. Ideally, one wants to measure the ease with which companies in need of external funds can access them and the ease with which investors can get adequate returns. This points back to the services offered by financial systems (see the discussion in Section 2.1) and would suggest measures related to the efficiency and competitiveness of the financial sector. However, time series data are generally available only for size indicators. Therefore, the standard practice in empirical research is to use measures of components of the financial system (relative to GDP). As each of them has some shortcomings as a measure of services, a set of three indicators is used here.

- Liquid liabilities, consisting of currency and interest-bearing liabilities of bank and non-bank financial intermediaries, is intended as a measure of the overall size of the financial intermediary system. However, because it fails to exclude deposits by one financial

28. Bassanini, Scarpetta and Hemmings (2001) [BSH] and the present paper are both drawn from a wider research effort conducted at the OECD on the factors determining economic growth. This paper focuses on financial system contributions to growth, while BSH looks at a broader range of factors, including financial system contributions. As a consequence, this paper will at times refer to results from $\mathrm{BSH}$, to the extent that the results are relevant for the discussion of financial system contributions to growth.

29. A comprehensive set of financial development indicators is provided in the World Bank's financial development database (for a description see Beck, Demirgüç-Kunt and Levine, 1999), from which the present indicators are obtained. All indicators are expressed as a share of GDP. 
intermediary in another, these unconsolidated data embody "double counting", which may well differ across countries and over time.

- Private credit of deposit money banks provided to the private sector, consisting of the total claims of deposit money banks on the private sector, aims to measure the degree of financial intermediation that occurs in the banking system. It has the advantage that it isolates credit issued to the private sector, as opposed to credit issued to governments, government agencies, and public enterprises. A major shortcoming is that it captures only the financing intermediated by deposit banks and not the financing through other institutions or the securities markets. ${ }^{30}$

- Stock market capitalisation, consisting of the value of listed shares, attempts to measure the ease with which funds can be raised in the equity market. One limitation is that it does not capture the development of the banking system, the role of debt securities, or other parts of the equity market (non-listed equity). Another possible limitation is that it measures the market value of existing listed companies rather than the amount of funds raised in the equity market in any particular year -- though, on the other hand, changes in stock market valuations may play an important signalling role as concerns expected returns on investment. Also, such a size measure does not necessarily indicate the ease and efficiency with which firms or companies can raise funds through issuing equities. Indicators of activity and liquidity would be useful in this context; however, sufficiently long time series of these indicators are not generally available for a large number of OECD countries.

- In addition, the first principal component of two or all three of these measures is extracted and used alternatively as a financial development measure. While the precise contribution of the underlying variables cannot be identified with this technique, the first principal component may be seen as a parsimonious indicator for overall financial development, and it captures an important part of the variance structure of the combined financial development measures.

33. The level of financial development, as measured by the first three indicators, varies considerably across countries and often over time (Figures 3 to 5). While the level of financial depth has increased in almost all sample countries from 1970 to 1997, the pace of deepening has differed across countries. As well, the rate of change has been uneven over time within the same country, e.g. rapid acceleration in banking-sector and stock-market development in the United Kingdom and Japan, respectively, in the 1980s. Furthermore, while the three indicators are, for the most part, positively correlated with each other in each country, the correlation is often not high, and important changes in the relative size of the different indicators have occurred. ${ }^{31}$ In any case, the relative sizes of the three indicators with respect to each other differ across countries, reflecting differences in their financial structures. Finally, two of these indicators, private credit and stock market capitalisation, show some correlation with the compound measure of

30. An alternative measure is total claims of deposit banks and other financial institutions, the latter including insurance companies, finance companies, pooled investment schemes (mutual funds) savings banks, private pension funds and development banks. This measure, which might be preferred, is not chosen here because of apparent inconsistencies in the coverage of the data. Specifically, for some countries data for claims of other financial institutions are missing both at the end and at the beginning of the sample. In those cases the values given for private credit of deposit money banks and other financial institutions are the same as for private credit of deposit money banks.

31. The sample correlations of liquid liabilities with private credit and stock market capitalisation are 0.72 and 0.25 , respectively. The correlation of private credit with stock market capitalisation is 0.35 . 
investor protection discussed in the previous section (Figure 6). This may be interpreted as a sign that investor protection provides support for the deepening of financial development.

34. Gross investment is measured here by real private non-residential (or business sector) fixed capital formation. Business-sector fixed investment probably captures the bulk of productive capital accumulation in OECD economies. It excludes other categories of private-sector investment, such as residential construction and stockbuilding, which are generally not driven by the same factors. The growth in gross investment during the sample period from 1970 to 1997 differs across countries and over time (Figure 7), with e.g. a period of low growth in the early 1980s and one with high growth in the second half of the 1980s. Focusing on the time-series behaviour of the indicators of financial development and gross fixed investment, there is positive correlation in most countries (Table 4), a necessary (but not sufficient) condition for a long-run positive relationship between these variables (though not revealing any information about causality).

\subsection{Financial development and investment levels}

35. This section describes two approaches to examine the link between financial development and investment. Both approaches treat investment as a function of an indicator of financial development and a set of more standard conditioning variables. The financial development indicator serves as a proxy measure of the services provided by a financial system that might influence the financial cost of capital, ease the acquisition of financing, expand the range of financing opportunities, or otherwise help to bring savers and investors together more efficiently, as described in Section 2.1. The two approaches differ in the set of conditioning variables they employ and the constraints they impose.

\subsubsection{The first approach}

36. Empirical models of investment typically include measures of output and cost (Ford and Poret, 1990; Chirinko, 1993). The first approach follows along these lines. It takes the (log) level of gross investment as its dependent variable and the following as its long-run conditioning variables: (i) the (log) level of output and (ii) a real long-term interest rate, adjusted for relative price changes between capital goods and output. ${ }^{32}$ In addition, the approach includes one of the indicators of financial development described in Section 4.1. To focus on the long-run contribution of financial development to investment, a panel error correction approach is adopted for the empirical analysis. Such an approach has the advantage that it distinguishes the long-run determination of investment -- the primary focus here -- from the shortrun adjustment.

37. Four techniques are used to estimate the relationship between financial development and gross investment, all variations of an error-correction approach (detailed functional forms are given in the appendix).

32. The output variable in the estimation is the log of real private gross domestic product. The adjusted real long-term interest rate is the $\log (1+r)$, where $r$ is the product of a long-term real interest rate (derived from government securities) and the ratio of a deflator of private non-residential fixed capital formation to an output price deflator. This expression would form part of a measure of the user cost of capital (Jorgenson, 1967; Chirinko, 1993). A more complete measure, as might be used in a detailed study of investment in a single country, would also account for depreciation and institutional and tax factors. Such detail is beyond the scope of the current study, which is focused more broadly on the effects of financial development in a cross-section of countries. 
- At one extreme is the dynamic fixed effects estimator, which imposes the constraint that the short and long-run coefficients are equal across countries ("pooling").

- At the other extreme is the mean group estimator, which does not impose any restriction; it is an unweighted average of the coefficients estimated independently for each country.

- The pooled mean group estimator takes an intermediate position, involving both pooling and averaging (Pesaran, Shin and Smith, 1998). It imposes equality of long-run coefficients ("pooling") but allows short-run coefficients to differ across countries ("averaging").

- In addition to these three, a static fixed effects estimator is used to provide comparability with many earlier studies. This method includes only contemporaneous variables ("static") and is a special case of an error correction model where the coefficient on the error correction term is constrained to be equal to one.

\subsubsection{Estimation results for the first approach ${ }^{33}$}

38. Table 5 summarises the results for each measure of financial development using the four different estimation techniques discussed above (only the long-run coefficient estimates are reported in the table). In all cases the dependent variable is the log change in gross investment. Under the assumption that the longrun elasticities are identical across countries but allowing the short-run elasticities to vary (i.e. using the pooled mean group estimator) ${ }^{34}$ there is significant support for the hypothesis that financial development is linked to gross investment in OECD countries. This holds when financial development is measured by stock market development or by private credit of deposit money banks. To a somewhat lesser extent (significant only at the 5 per cent rather than the 1 per cent level), the result is maintained when financial development is measured by liquid liabilities.

39. The results here are consistent with previous work on the topic, but they also go beyond it and reconcile some differences in earlier conclusions (Table 6). For example, while De Gregorio and Guidotti (1995) found statistically significant links between finance and the level of investment, Fernandez and Galetovic (1994) failed to do so using similar techniques (variations of the static fixed effects method). This likely reflects the use of liquid liabilities as a financial development measure in the latter and of

33. The sample consists of an unbalanced panel of data from 1970 to 1997 for 19 OECD countries reflecting limitations to data availability. The sample includes: Australia, Austria, Belgium, Canada, Denmark, Finland, France, Germany, Greece, Italy, Japan, Netherlands, New Zealand, Norway, Spain, Sweden, Switzerland, United Kingdom and United States. In cases where less than 20 observations were available for a country, it was eliminated from the regression specification. In the specifications where financial development was measured by data on stock market capitalisation, Finland, New Zealand and Norway (with 15, 13 and 17 observations, respectively) were excluded.

34. The estimation results confirm that the pooled mean group estimator takes a reasonable middle ground between the other estimators considered here. On the one hand, the dynamic fixed effects estimator appears to be too restrictive. Specifically, in the cases of the mean group or the pooled mean group estimators where the constraint of equality of short-run coefficients across countries are relaxed, the estimates of the short-run coefficients turn out to be considerably different between countries. (The estimates of coefficients for the short-run adjustment other than the coefficient for the error correction term are not shown in the tables to save space, and because the primary interest is in the long-run relationships.) On the other hand, the mean group estimator appears to be very sensitive to outliers. Compared to the mean group estimates, the pooled mean group estimates are more robust, as the country-specific estimates with higher variance have a smaller weight in the overall coefficient estimates when the pooled mean group estimator is used. 
private credit in the former (see comparable results in Table 5). The results here expand on those in King and Levine (1993), who found strong results for non-OECD countries but failed to do so for OECD countries, using both of these measures. Finally, Black and Moersch (1998) found only private credit but not stock market capitalisation to be significantly related to investment for (their full sample of) OECD countries. This failure to find a significant coefficient estimate for stock market capitalisation may reflect that their sample included fewer recent observations than that used here. Robustness testing of the estimates shows that the effect of private credit diminishes and the effect of stock market capitalisation increases as the sample includes more recent observations (see Box). ${ }^{35}$

\section{Box. Robustness of results}

Experimenting with variations of the regressions (using the pooled mean group estimator) points to robustness of results regarding the finance-investment link. For example, the regressions for the three financial development measures were re-estimated for all the possible sub-samples obtained by deleting one country at a time from the original sample. The estimated financial development coefficients are shown in Figure 8, after arranging the estimates in decreasing order across sub-samples. In the case of both private credit and stock market capitalisation, the sample composition does not make a significant difference in terms of the estimated coefficient. In the case of stock market capitalisation, the results are remarkably stable except if Japan is removed; however, even then, the coefficient remains significantly different from zero.

Other types of robustness tests also support the current specification. For example, private credit and stock market development remain significantly positive, even when a second financial development measure is included in the specification (Models 1 and 2 in Table 7). Also, the first principal components calculated for different combinations of the financial development measures, and included alternatively in the regression instead of the measures themselves, were always positive and highly significant (Models 3 to 5 in Table 7). Furthermore, when investment is expressed as a percentage of real private GDP and other regressors are added to the specification, as described in Section 4.2.4, the coefficient estimates of the financial development measures remain mostly significant.

When the sample period is shortened, the coefficient estimates for private credit of deposit money banks and for stock market capitalisation exhibit some fluctuations (Figure 9). The regressions for the two financial development measures were re-estimated for all the possible sub-samples obtained by shortening the sample through dropping the most recent year, until 1989. The coefficient estimates for private credit of deposit money banks become relatively smaller as the sample increases to include successive years of the 1990s. By contrast, the estimates for the stock market are broadly flat, and even rise, as the most recent observations for 1996 and 1997 are included. Whether the latter represents a shift in the effect or just random fluctuation can only be judged as more data become available. If the new pattern persists, it would be consistent with the hypothesis that the relative importance for investment of the stock market has increased as compared to the banking sector.

40. Four additional conclusions emerge from the results shown in Table 5. First, the coefficient estimates for output are positive and strongly significant, but often statistically greater than one. Experimentation with the inclusion of additional independent variables, such as inflation, government spending and human capital, caused the coefficient estimate for the output variable to vary, but it,

35. A distinction is often made between either bank-based or market-based financial systems (e.g. Block and Moersch, 1998). Testing explicitly for the implications of different types of systems for investment is beyond the scope of the present analysis. Because the method is considered to be generally reliable only when both the number of time series $(\mathrm{T})$ and cross-section $(\mathrm{N})$ observations are relatively large, sample size is a concern with the estimators used here. Pesaran, Shin and Smith (1998) suggest that $\mathrm{T}=32$ and $\mathrm{N}=24$ is "quite large" and that $\mathrm{T}=17$ and $\mathrm{N}=10$ is "quite small". Splitting our sample with $\mathrm{N}=19$ countries into two or more groups and estimating separate regressions for each in turn would imply that the number of $\mathrm{N}$ in these sub-samples would be quite small. 
nonetheless, remained significantly above one. A coefficient estimate greater than one may be seen as inconsistent with a constant capital output ratio in the steady state. In the approach used here, however, it is possible that the short-run dynamics of the specification failed to capture all the business cycle effects and that the long-run estimate is picking up the effects of an accelerator-type relationship. In addition, in an environment of steadily declining relative prices for capital, the real stock of capital, quality adjusted could grow faster than real output for a long period. In this case, the high coefficient on output may be an indication that the sample considered here is too short to have captured a true steady-state relationship. It is also possible that the coefficient estimate on the output variable is picking up additional effects associated with an omitted trending variable that is correlated with output. As shown in Section 4.2.4, however, constraining the income coefficient to be equal to one has little effect on the estimate of the coefficient on financial development. Second, the coefficient estimate for the adjusted real interest rate is mostly insignificant, irrespective of the choice of estimator or financial development measure. ${ }^{36}$ This likely reflects the inability of the adjusted real interest rate to capture the appropriate user costs of capital. Moreover, there may be problems of collinearity between the (adjusted) real interest rate and measures of financial development. ${ }^{37}$ Third, common to all the dynamic estimators is that the error correction term has an estimated coefficient that is negative and significant. This is consistent with the view that there exists a long-run equilibrium relationship between the variables and that the short-run adjustment is driven by the extent of the gap between current and long-run equilibrium values. Fourth, the joint test of the long-run homogeneity of the slope coefficients indicates that these restrictions are not rejected.

\subsubsection{The second approach}

41. The second approach can, in one respect, be seen as a constrained version of the first approach. It takes the ratio of gross investment to output as its dependent variable -- in essence, imposing the constraint that the long-run coefficient on the output variable in the first approach equals one, consistent with a constant investment-output ratio in the steady-state. ${ }^{38}$ Another difference between the two approaches lies in the conditioning set, which includes policy and other variables found to be important in the study of growth in Bassanini, Scarpetta and Hemmings (2001). The conditioning set includes varying combinations of: (i) inflation, (ii) the standard deviation of inflation, (iii) government capital formation, (iv) government consumption, (v) government tax receipts and (vi) adjusted trade exposure. ${ }^{39}$ Finally, only the two more promising measures of financial development -- private credit of deposit money banks and stock market capitalisation -- are examined here. The pooled mean group estimator is used to estimate the various specifications.

36. Ford and Poret (1990) report that many studies "have concluded that there is little or no empirical evidence that the cost of capital affects investment demand". Chirinko (1993), in his survey of investment, corroborates this finding and claims that investment appears to be "most sensitive to quantity variables (output or sales) with price variables having only modest effects".

37. The sample correlations between the adjusted real interest rate and the measures of liquid liabilities, private credit, and stock market capitalisation are $-0.01,0.18$ and 0.26 , respectively.

38. Because of minor differences in the dating and definition of the output proxy in the two approaches, an exact equivalence does not result from imposing a unit coefficient on the output variable. However, in the steady state, such differences should be immaterial.

39. Further details on the variables in the conditioning set can be found in Bassanini, Scarpetta and Hemmings (2001). 


\subsubsection{Estimation results for the second approach}

42. The results reported here for the second approach are drawn from Bassanini, Scarpetta and Hemmings (2001). They provide additional support for the view of positive linkages between financial development and investment (Table 8). Two specifications using private credit of deposit money banks as the financial development measure and two using stock market capitalisation are presented. The signs and magnitudes of the estimated coefficients on the financial variables, even after controlling for a number of different policy and framework conditions, are similar to those delivered by the pooled mean group estimator in the first approach. As before, the estimates for private credit are somewhat weaker than for stock market capitalisation, which are all significantly different from zero.

\subsection{Financial development and growth}

43. The preceding results identify a positive and generally significant relationship between financial development and the level of investment. Coupled with the result that investment contributes directly to economic activity and growth [see Bassanini, Scarpetta and Hemmings (2001)], financial development can be seen to have a role in the growth process.

44. Financial development may also contribute to economic activity through other channels, such as technical innovation or through improved efficiency of investment or factor allocation more generally. Table 9, which is also taken from Bassanini, Scarpetta and Hemmings (2001), provides evidence of the existence of such channels. In the specification shown, the long-run level of output per capita is a function of a financial development indicator, investment as a share of output, human capital and other conditioning variables. Even controlling for investment in fixed and human capital, the financial development indicators show a positive and significant association with output, consistent with the view that channels other than fixed investment may link financial development to economic activity and growth. The exact channel is difficult to identify, however. Because of data limitations, research and development could not be controlled for in the estimations which include measures of financial development.

45. As a means of interpreting the estimation results and gauging how reasonable they are, the coefficient estimates can be used to evaluate an average impact of increases in the shares of private credit and stock market capitalisation to GDP, taking into account effects on growth arising through the level of fixed investment and through other channels (Table 10). While such an exercise can be criticised for combining, perhaps inappropriately, the results of different estimations, it is used here in two examples to provide rough orders of magnitude.

46. The first example considers differences of 10 percentage points in the shares of private credit and stock market capitalisation, which correspond to less than a tenth of the cross-country range of each financial development indicator in 1997. These yield differences of about 0.5 and 0.7 per cent, respectively, in the level of GDP per capita through the investment channel. ${ }^{40}$ The impact on output through alternative channels is considerably larger, particularly for stock market capitalisation, which delivers a 2.6 per cent difference in GDP per capita, compared with a 0.7 per cent adjustment from private credit issued by deposit money banks. The combined impact on GDP per capita of each change in financial depth is 1.1 per cent for private credit and 3.3 per cent for stock market capitalisation. The second (and more extreme) example considers the impact on long-run GDP per capita of increasing the stock market capitalisation relative to GDP in a country where it is currently low to the level of a country where it is currently high. Were Greece to increase (somehow) its stock market capitalisation ratio to that of the

40. The GDP per capita variable used in the estimation is real GDP in PPP terms divided by the working age population. 
United States, these estimates imply that the long-run level of GDP per capita in Greece could increase 20 per cent. ${ }^{41}$ Such an increase is equivalent to about a third of the GDP gap between the two countries in $1996 .{ }^{42}$ Whether such a substantial role for financial depth is a credible result is difficult to judge.

47. These results are only suggestive of the importance of financial development in economic activity and growth. The evidence supports the view that economies with deeper and broader financial system development also have higher levels of investment, ceteris paribus, as well as higher levels of per capita GDP, possibly in association with greater efficiency and productivity. However, the estimation does not specify the policy measures that could be employed to increase financial development nor is it clear that the coefficient estimates would be the same if large changes in policy occurred.

\section{Summary and assessment}

48. Financial systems can in principle enhance growth through the provision of key services that mobilise savings, diversify risks and reduce monitoring costs associated with allocating savings and overseeing firms. Financial framework conditions influence the ways in which these services are provided in any particular financial system, although it is difficult to determine a priori the net effects of particular configurations of framework conditions on growth.

49. Examination of the empirical links between framework conditions and innovation, investment and growth reveals some tentative links between investor protections, and particularly their enforcement, to innovation in OECD countries. The change in MFP growth from the 1980s to 1990s also exhibits a positive relationship with investor protection. Given the number of countries involved and the lack of time series observations on the framework conditions, study of these relationships is limited to consideration of simple, bi-variate relationships that can be seen as suggestive of possible structural relationships. Links between the indicators of framework conditions and broader measures of investment and growth could not be identified using these methods.

50. With indicators of the scale of financial system development, which do have a time dimension, more detailed analysis of the links between financial systems and growth are possible. This paper provides evidence that financial development is related to economic growth through its relationship with fixed investment and through other channels. Different indicators of financial development are used. The results appear to be strongest for stock market capitalisation, although the contribution of private credit issued by deposit money banks is also significant. These financial development variables are also shown to have positive links to the indicators of financial framework conditions.

51. The policy conclusions to be derived from this study can only be modest, at best. Questions remain regarding the direction of causation in these relationships. Furthermore, the empirical methods used to study the framework conditions are rudimentary, leaving the interpretation of results involving them open to question. Nonetheless, these methods suggest that innovation is related to framework conditions and their enforcement. Furthermore, the possibility that stronger investor protections enhance financial system development suggests a channel through which such framework conditions could ultimately stimulate investment. And financial system development, driven by framework conditions, may have effects on growth that go beyond those associated with the accumulation of fixed capital, working through

41. In this example, the increase in stock market shares is from 24 per cent to 122 per cent.

42. In principle this increase should be compared to the gap between long-run equilibrium levels of GDP per capita, not the actual levels. The discrepancy is less important, however, if the gaps between actual levels of GDP used for Greece and the United States and their respective long-run GDP levels are comparable. 
ECO/WKP(2001)6

investment in research and development, development and diffusion of technological progress, or more efficient factor allocation. 


\section{APPENDIX. ESTIMATION METHODS AND DATA DEFINITIONS AND SOURCES}

\section{Estimation methods}

Three versions of error correction approaches are used here, the pooled mean group estimator suggested by Pesaran, Shin and Smith (1998), the mean group estimators and the dynamic fixed effects estimator. The first two approaches are designed for samples in which $T$, the number of time series observations, and $N$, the number of countries, are relatively large (about 20 to 30 countries according to Pesaran et al.) and of roughly the same order of magnitude.

For easier comparison of the different approaches, an $\operatorname{ARDL}(1,1,1,1)$ is used as a benchmark specification, where the numbers in parentheses stand for the lag length of the lagged dependent and the three explanatory variables. ${ }^{43}$ The unrestricted specification is as follows:

$$
i b v_{i, t}=\mu_{i}+\delta_{10 i} g d p_{i, t}+\delta_{11 i} g d p_{i, t-1}+\delta_{20 i} i r l_{i, t}+\delta_{21 i} i r l_{i, t-1}+\delta_{30 i} f i n_{i, t}+\delta_{31 i} f i n_{i, t-1}+\lambda_{i} i b v_{i, t-1}+\varepsilon_{i t}
$$

where $i b v_{i, t}, g d p_{i, t}, i r l_{i, t}$ and $f i n_{i, t}$ are respectively real gross investment, real gross domestic product, adjusted real long-term interest rate and a financial development measure (liquid liabilities, stock market capitalisation, private credit). This equation (1) can be written in the form of an error correction model (ECM):

$$
\Delta i b v_{i, t}=\mu_{i}+\phi_{i}\left(i b v_{i, t-1}-\theta_{1 i} g d p_{i, t}-\theta_{2 i} i r l_{i, t}-\theta_{3 i} f i n_{i, t}\right)-\delta_{11 i} \Delta g d p_{i, t}-\delta_{21 i} \Delta i r l_{i, t}-\delta_{31 i} \Delta f i n_{i, t}+\varepsilon_{i t}
$$

where $\theta_{1 i}=\frac{\delta_{10 i}+\delta_{11 i}}{1-\lambda_{i}}, \theta_{2 i}=\frac{\delta_{20 i}+\delta_{21 i}}{1-\lambda_{i}}, \theta_{3 i}=\frac{\delta_{30 i}+\delta_{31 i}}{1-\lambda_{i}}$ are the long-run coefficients and $\phi_{i}=1-\lambda_{i}$ is the adjustment coefficient, and $\Delta$ is the first order difference operator. On the basis of equation (2) the three approaches can be distinguished according to the restrictions imposed by each of them (Table A.1).

43. The lag order actually used in the estimates was determined by the statistical fit. The maximum lag order was set to two, which seemed to provide a good compromise between achieving necessary flexibility (suggesting a high maximum lag order) and having sufficiently long times series observations available (suggesting a low lag order). After having set the maximum lag order, the lags for the individual variables were determined on the basis of the Schwarz-Bayesian Criterion. 
ECO/WKP(2001)6

Table A.1. Comparison of estimators according to restrictions imposed

\begin{tabular}{l|l|c}
\hline \multicolumn{1}{c|}{ Estimators } & \multicolumn{1}{|c}{ Type of parameters restrictions } & Number of restrictions \\
\hline $\begin{array}{l}\text { Mean group } \\
\text { estimator }\end{array}$ & No restriction. & 0 \\
\hline $\begin{array}{l}\text { Pooled mean group } \\
\text { estimator }\end{array}$ & $\theta_{1 i}=\theta_{1}, \theta_{2 i}=\theta_{2}, \theta_{3 i}=\theta_{3} \quad \forall i=1, \ldots N$. & $3^{\star}(N-1)$ \\
\hline $\begin{array}{l}\text { Dynamic fixed } \\
\text { effects estimator }\end{array}$ & $\theta_{1 i}=\theta_{1}, \theta_{2 i}=\theta_{2}, \theta_{3 i}=\theta_{3} \quad \forall i=1, \ldots N$. & $7^{*}(N-1)$ \\
& $\sigma_{i}^{2}=\sigma^{2} \quad \forall i=1, \ldots, N$. & \\
& $\delta_{11 i}=\delta_{11}, \delta_{21 i}=\delta_{21}, \delta_{31 i}=\delta_{31} \quad \forall i=1, \ldots, N$. & \\
& Only $\mu_{i}$ differ freely across countries. & \\
\hline
\end{tabular}

Note: $\quad \mu_{i}$ is the country-specific intercept, $\theta=\left(\theta_{1}, \theta_{2}, \theta_{3}\right)^{\prime}$ is the vector of long-run coefficients, $\sigma_{i}^{2}$ is the standard error of the estimate of country $i$ and $\delta=\left(\delta_{11}, \delta_{21}, \delta_{31}\right)$ 'is the vector of short-run coefficients and $N$ is the number of countries.

\subsection{Mean group estimator}

The mean group estimator consists of estimating $N$ separate regressions and calculating the coefficients as unweighted means of the estimated coefficients for the individual countries. This does not impose any restrictions on the short-run and long-run coefficients or the error variances. In this respect, this method is less restrictive than the pooled mean group estimator or dynamic fixed effects estimator. However, even if it is consistent, it will tend to be sensitive to the outliers for finite samples, because the outlier is given the same weight as other observations. Its specification is as follows:

$$
\Delta i b v_{i, t}=\mu_{i}+\phi_{i}\left(i b v_{i, t-1}-\theta_{1 i} g d p_{i, t}-\theta_{2 i} i r l_{i, t}-\theta_{3 i} f i n_{i, t}\right)-\delta_{11 i} \Delta g d p_{i, t}-\delta_{21 i} \Delta i r l_{i, t}-\delta_{31 i} \Delta f i n_{i, t}+\varepsilon_{i t}
$$

\subsection{Dynamic fixed effects estimator}

At the other extreme is the dynamic fixed effects estimator which imposes equality of all slope coefficients and error variances, allowing only the intercepts to differ across countries. The parameters are treated as fixed because we are not using samples but almost the whole population of countries in a particular category: members of the OECD (see also Pesaran, Shin and Smith, 1998). The dynamic fixed effects estimator is more restrictive than both the pooled mean group and mean group estimators. One has to justify the homogeneity of short-run coefficients across countries. Therefore, when homogeneity is imposed incorrectly it can lead to heterogeneity biases in the pooled estimators. This bias is likely to be smaller in the case of the pooled mean group estimator and does not exist when using the mean group estimator. Its specification is as follows:

$$
\Delta i b v_{i, t}=\mu_{i}+\phi_{i}\left(i b v_{i, t-1}-\theta_{1} g d p_{i, t}-\theta_{2} i r l_{i, t}-\theta_{3} f i n_{i, t}\right)-\delta_{11} \Delta g d p_{i, t}-\delta_{21} \Delta i r l_{i, t}-\delta_{31} \Delta f i n_{i, t}+\varepsilon_{i t}
$$


A special case of the dynamic fixed effects estimator is the static fixed effects estimator:

$$
i b v_{i, t}=\theta_{1} g d p_{i, t}+\theta_{2} i r l_{i, t}+\theta_{3} f_{i n}+\mu_{i, t}+\varepsilon_{i, t}
$$

It can be written similar to an error correction model in the following form:

$$
\Delta i b v_{i, t}=-\left(i b v_{i, t-1}-\theta_{1} g d p_{i, t}-\theta_{2} i r l_{i, t}-\theta_{3} f i n_{i, t}\right)+\mu_{i}+\varepsilon_{i, t}
$$

\subsection{Pooled mean group estimator}

The pooled mean group estimator can be interpreted as an intermediate procedure between these extreme approaches because it involves both pooling and averaging. This estimator allows short-run coefficients, including the adjustment coefficient, and error variances to differ across countries, while the long-run coefficients are constrained to be the same. This has two aspects. First, imposing equality restrictions, if they are valid, will increase the efficiency of the estimates. Second, because the short-run slope coefficients are allowed to differ, the dynamic specification (lag length) can also differ across countries. The pooled mean group estimator is chosen here because the constraining of long-run coefficients permits us to focus on the long-run effects of financial development on investment, while allowing the short-run adjustment to the long run equilibrium values to differ country by country. There are good reasons to expect the long-run equilibrium relationships between variables to be similar across OECD countries or, at least, a sub-set of OECD countries, due to similar levels of financial development and financial structures, common technologies, and the openness of the economies with a tendency toward convergence. Its specification is as follows:

$$
\Delta i b v_{i, t}=\mu_{i}+\phi_{i}\left(i b v_{i, t-1}-\theta_{1} g d p_{i, t}-\theta_{2} i r l_{i, t}-\theta_{3} f i n_{i, t}\right)-\delta_{11 i} \Delta g d p_{i, t}-\delta_{21 i} \Delta i r l_{i, t}-\delta_{31 i} \Delta f i n_{i, t}+\varepsilon_{i t}
$$


ECO/WKP(2001)6

\section{Data definitions and sources for non-OECD data}

\begin{tabular}{|c|c|}
\hline \multicolumn{2}{|r|}{ Shareholder rights } \\
\hline One-share = one-vote & $\begin{array}{l}\text { Equals one if the Company Law or Commercial Code of the country requires that ordinary shares carry one } \\
\text { vote per share, and zero otherwise. Equivalently, this variable equals one when the law prohibits the } \\
\text { existence of both multiple-voting and non-voting ordinary shares and does not allow firms to set a maximum } \\
\text { number of votes per shareholder irrespective of the number of shares he owns, and zero otherwise. }\end{array}$ \\
\hline Voting by mail allowed & $\begin{array}{l}\text { Equals one if the company law or commercial code allows shareholders to mail their proxy vote to the firm, } \\
\text { and zero otherwise. }\end{array}$ \\
\hline $\begin{array}{l}\text { Shares not blocked } \\
\text { before meeting }\end{array}$ & $\begin{array}{l}\text { Equals one if the company law or commercial code does not allow firms to require that shareholders deposit } \\
\text { their shares prior to a general shareholders meeting, thus preventing them from selling those shares for a } \\
\text { number of days, and zero otherwise. }\end{array}$ \\
\hline $\begin{array}{l}\text { Cumulative voting or } \\
\text { proportional } \\
\text { representation }\end{array}$ & $\begin{array}{l}\text { Equals one if the company law or commercial code allows shareholders to cast all their votes for one } \\
\text { candidate standing for election to the board of directors (cumulative voting) or if the company law or } \\
\text { commercial code allows a mechanism of proportional representation in the board by which minority interests } \\
\text { may name a proportional number of directors to the board, and zero otherwise. }\end{array}$ \\
\hline $\begin{array}{l}\text { Oppressed minority } \\
\text { protection }\end{array}$ & $\begin{array}{l}\text { Equals one if the company law or commercial code grants minority shareholders either a judicial venue to } \\
\text { challenge the decisions of management or of the assembly or the right to step out of the company by } \\
\text { requiring the company to purchase their shares when they object to certain fundamental changes, such as } \\
\text { mergers. asset dispositions, and changes in the articles of incorporation. The variable equals zero } \\
\text { otherwise. Minority shareholders are defined as those shareholders that own } 10 \text { per cent of share capital or } \\
\text { less. }\end{array}$ \\
\hline Pre-emptive rights & $\begin{array}{l}\text { Equals one when the company law or commercial code grants shareholders the first opportunity to buy new } \\
\text { issues of stock, and this right can be waived only by a shareholders' vote; equals zero otherwise. }\end{array}$ \\
\hline $\begin{array}{l}\text { Percentage of share } \\
\text { capital to call an } \\
\text { extraordinary } \\
\text { shareholders' meeting }\end{array}$ & $\begin{array}{l}\text { The minimum percentage of ownership of share capital that entitles a shareholder to call for an } \\
\text { extraordinary shareholders' meeting; it ranges from } 1 \text { to } 33 \text { per cent. }\end{array}$ \\
\hline & Source for data on shareholder rights: Company law or commercial code, from La Porta et al. (1998). \\
\hline \multicolumn{2}{|r|}{ Creditor rights } \\
\hline $\begin{array}{l}\text { No automatic stay on } \\
\text { secured assets }\end{array}$ & $\begin{array}{l}\text { Equals one if the reorganisation procedure does not impose an automatic stay on the assets of the firm on } \\
\text { filing the reorganisation petition. Automatic stay prevents secured creditors from gaining possession of their } \\
\text { security. It equals zero if such a restriction does exist in the law. }\end{array}$ \\
\hline Secured creditors first & $\begin{array}{l}\text { Equals one if secured creditors are ranked first in the distribution of the proceeds that result from the } \\
\text { disposition of the assets of a bankrupt firm. Equals zero if non-secured creditors, such as the government } \\
\text { and workers, are given absolute priority. }\end{array}$ \\
\hline $\begin{array}{l}\text { Restrictions on going } \\
\text { into reorganisation }\end{array}$ & $\begin{array}{l}\text { Equals one if the reorganisation procedure imposes restrictions, such as creditors consent, to file for } \\
\text { reorganisation; equals zero if there are no such restrictions. }\end{array}$ \\
\hline $\begin{array}{l}\text { Management does not } \\
\text { stay }\end{array}$ & $\begin{array}{l}\text { Equals one when an official appointed by the court, or by the creditors, is responsible for the operation of } \\
\text { the business during reorganisation. Equivalently, this variable equals one if the debtor does not keep the } \\
\text { administration of its property pending the resolution of the reorganisation process. Equals zero otherwise. }\end{array}$ \\
\hline & Source for data on creditor rights: Bankruptcy and reorganisation laws, from La Porta et al. (1998). \\
\hline
\end{tabular}


ECO/WKP(2001)6

\section{Enforcement and transparency}

Observance of laws and regulations (a)

Observance of laws and regulations (b)

Efficiency of judicial system

Policy effectiveness

Risk of contract repudiation

Rating on accounting standards
Assessment of the law and order tradition ("rule of law") in the country produced by the country risk rating agency International Country Risk (ICR). Average of the months of April and October of the monthly index between 1982 and 1995. Scale from zero to 10, with lower scores for less tradition for law and order (scale was changed from its original range going from zero to six).

Source: International Country Risk guide, from La Porta et al. (1998).

Estimate of an aggregate indicator using an unobserved components model, in which the observed data are expressed as a linear function of the unobserved aggregate indicator plus a disturbance term capturing perception errors and/or sampling variation in each indicator. The observed data are 42 individual indicators on "rule of law" from 11 different sources, based on data referring to 1997/98. The aggregate indicator was rescaled to range from zero to 10, with lower scores for less rule of law (original range from -2.5 to 2.5).

Source: Kaufmann et al. (1999a,b).

Assessment of the "efficiency and integrity of the legal environment as it affects business, particularly foreign firms" produced by the country risk rating agency Business International Corp. It "may be taken to represent investors' assessments of conditions in the country in question." Average between 1980 and 1983. Scale from zero to 10; with lower scores, lower efficiency levels.

Source: Business International Corporation, from La Porta et al. (1998).

Estimate of an aggregate indicator using an unobserved components model, in which the observed data are expressed as a linear function of the unobserved aggregate indicator plus a disturbance term capturing perception errors and/or sampling variation in each indicator. The observed data are 31 individual indicators on "government effectiveness" from 9 different sources, based on data referring to 1997/98. The aggregate indicator was rescaled to range from zero to 10, with lower scores for less government effectiveness (original range from -2.5 to 2.5 ).

Source: Kaufmann et al. (1999a,b).

ICR's assessment of the "risk of a modification in a contract taking the form of a repudiation, postponement, or scaling down" due to "budget cut-backs, indigenisation pressure, a change in government, or a change in government economic and social priorities." Average of the months of April and October of the monthly index between 1982 and 1995. Scale from zero to 10, with lower scores for higher risks.

Source: International Country Risk Guide, from La Porta et al. (1998).

Index created by examining and rating companies' 1990 annual reports on their inclusion or omission of 90 items. These items fall into seven categories (general information, income statements, balance sheets, funds flow statement, accounting standards, stock data, and special items). A minimum of three companies in each country was studied. The companies represent a cross section of various industry groups; industrial companies represented 70 per cent, and financial companies represented the remaining 30 per cent.

Source: International accounting and auditing trends, Center for International Financial Analysis and Research; La Porta et al. (1998).

\section{Financial Development}

\begin{tabular}{|c|c|}
\hline Liquid liabilities & Currency and interest-bearing liabilities of bank and non-bank financial intermediaries divided by GDP. \\
\hline $\begin{array}{l}\text { Private credit of } \\
\text { deposit money banks } \\
\text { provided to the private } \\
\text { sector }\end{array}$ & Total claims of deposit money banks on the private sector, divided by GDP. \\
\hline \multirow{2}{*}{$\begin{array}{l}\text { Stock market } \\
\text { capitalisation }\end{array}$} & Value of listed shares divided by GDP. \\
\hline & Source: World Bank financial development database described in Beck, Demirgüç-Kunt and Levine (1999). \\
\hline \multicolumn{2}{|r|}{ Other } \\
\hline \multirow[t]{2}{*}{ IPOs/Pop } & $\begin{array}{l}\text { Ratio of the number of initial public offerings of equity in a given country to its population (in millions) for the } \\
\text { period 1995:7-1996:6. }\end{array}$ \\
\hline & $\begin{array}{l}\text { Source: Securities Data Corporation, AsiaMoney, LatinFinance, GT Guide to World Equity Markets, and } \\
\text { World Development Report 1996, from La Porta et al. (1997). }\end{array}$ \\
\hline
\end{tabular}




\section{BIBLIOGRAPHY}

ALLSOPP, C. and A. GLYN (1999), "The assessment: real interest rates", Oxford Review of Economic Policy, Vol. 15, Issue 2, pp. 1-16.

AMANO, R.A. (1995), "Empirical evidence on the cost of adjustment and dynamic labour demand", Bank of Canada Working Paper, No. 95-3.

ANDERSEN, P. and W. WHITE (1996), "The macroeconomic effects of financial sector reform: an overview of industrial countries", OECD Proceedings: Macroeconomic Policies and Structural Reform, pp. 59-104.

ANDRÉS, J., I. HERNANDO and J.D. LÓPES-SALIDO (1999), "The role of the financial system in the growth inflation link: the OECD experience", Banco de España Working Paper, October.

ARRELANO, M. and S. BOND (1991), "Some tests of specification for panel data: Monte Carlo evidence and an application to employment equations", Review of Economic Studies 58, pp. 277-297.

BALTAGI, B.H. and C. KAO (2000), "Non-stationary panels, cointegration in panels and dynamic panels: a survey", Department of Economics College Station, Center for Policy Research, 7 June.

BASSANINI, A., S. SCARPETTA and P. HEMMINGS (2001), "Economic growth: The role of policies and institutions. Panel data evidence from OECD countries", OECD Economics Department Working Papers No. 283, Paris.

BASSANINI, A., S. SCARPETTA and I. VISCO (2000), "Knowledge, technology and economic growth: recent evidence from OECD countries", OECD Economics Department Working Papers No. 259, Paris.

BAYOUMI, T. (1999), "The morning after: explaining the slowdown in Japanese growth in the 1990s", NBER Working Paper, No. 7350.

BECHT, M. and E. BOHMER (1999), "Ownership and voting power in Germany", in Barca, F. and M. Becht (eds.), Ownership and Control: A European Perspective, (forthcoming).

BECHT, M. and A. ROELL (1999), "Blockholdings in Europe; an international comparison”, European Economic Review 43, pp. 1049-1056.

BECHT, M., A. CHAPELLE and L. RENNEBOOG (1999), "Shareholding cascades: the separation of ownership and control in Belgium", in Barca, F. and M. Becht (eds.), Ownership and Control: A European Perspective, (forthcoming).

BECK, T., A. DEMIRGÜÇ-KUNT and R. LEVINE (1999), "A new database on financial development and structure", World Bank, mimeo, June.

BECK, T., R. LEVINE, and N. LOAYZA (2000), "Finance and the sources of growth", Journal of Financial Economics, 58, pp. 261-300. 
BENCEVINGA, V.R. and B.D. SMITH (1991), "Financial intermediation and endogenous growth", Review of Economic Studies, 58(2), April, pp. 195-209.

BERI (Business Environmental Risk Intelligence) (1995), Center for Institutional Reform and the Informal Sector (IRIS), BERI's Operations Risk Index, College Park: IRIS, University of Maryland.

BERLAGE, L. and D. TERWEDUWE (1988), "The classification of countries by cluster and by factor analysis", World Development, Vol. 16, No. 12, pp. 1527-1545.

BERTHELEMY, J-C. and A. VAROUDAKIS (1996), "Economic growth, convergence clubs, and the role of financial development”, Oxford Economic Papers, 48(2), April, pp. 300-328.

BIANCHI, M., M. BIANCO and L. ENRIQUES (1999), "Pyramidal groups and the separation between ownership and control in Italy", in Barca, F. and M. Becht (eds.), Ownership and Control: A European Perspective, (forthcoming).

BIRCH, D., A. HAGGERRY and W. PARSONS (1997), Corporate Almanac 1994, Cognetics Inc., Massachusetts.

BLACK, B.S. and R.J. GILSON (1998), "Venture capital and the structure of capital markets: banks versus stock markets", Journal of Financial Economics 47, pp. 243-77.

BLACK, S.W. and M. MOERSCH (1998), "Financial structure, investment, and economic growth in OECD countries", Chapter 7 in Competition and Convergence in Financial Markets Collection: Advances in Finance, Investment and Banking, North-Holland.

BLOCH, L. and E. KREMP (1999), "Ownership and voting power in France", in Barca, F. and M. Becht (eds.), Ownership and Control: A European Perspective, (forthcoming).

BLUNDELL, R. and S. BOND (1997), "Initial conditions and moment restrictions in dynamic panel data models", University College London Discussion Paper in Economics, pp. 97-07.

BOYLAUD, O. and G. NICOLETTI (2000), "Regulation, market structure and performance in telecommunications", OECD Economics Department Working Papers No. 237.

BRADLEY, M., G. JARRELL and E.H. KIM (1984), "On the existence of an optimal capital structure: theory and evidence", Journal of Finance 39, pp. 857-878.

CASELLI, P., P. PAGANO and F. SCHIVARDI (2000), "Investment and growth in Europe and in the United States in the nineties", Banca d'Italia Temi di discussione 372, March.

CENTER FOR INTERNATIONAL FINANCIAL ANALYSIS \& RESEARCH, Inc. (CIFAR) (1995), International Accounting and Auditing Trends, $4^{\text {th }}$ Edition, Vol. 1, International Accounting Trends, Princeton, NJ.

CHIRINKO, R.S. (1993), "Business fixed investment spending modelling strategies, empirical results, and policy implications", Journal of Economic Literature, Vol. XXXI, December, pp. 1875-1911.

CRESPI-CLADERA, R. and M. GARCIA-CESTONA (1999), "Ownership and control: a Spanish survey", in Barca, F. and M. Becht (eds.), Ownership and Control: A European Perspective, (forthcoming). 
DE GREGORIO, J. and P.E. GUIDOTTI (1995), "Financial development and economic growth", World Development, Vol. 23, No. 3, pp. 433-448.

DE JONG, A., R. KABIR, T. MARRA and A. ROELL (1999), "Ownership and control in the Netherlands" in Barca, F. and M. Becht (eds.), Ownership and Control: A European Perspective, (forthcoming).

DEMIRGÜÇ-KUNT, A. and R. LEVINE (1996), "Stock market development and financial intermediaries: stylized facts", World Bank Economic Review, Vol. 10, No. 2, pp. 291-321.

DEMIRGÜÇ-KUNT, A. and R. LEVINE (1999), Bank-Based and Market-Based Financial Systems: Cross-Country Comparisons, World Bank.

DEMIRGÜÇ-KUNT, A. and MAKSIMOVIC, V. (1996), "Stock market development and financing choices of firms", World Bank Economic Review, Vol. 10, No. 2, pp. 341-369.

DE SERRES A. (1995), "The review of the investment sector in CEFM: an error-correction approach", Ministry of Finance, Canada, mimeo, November.

DIAMOND, D. and P. DYBVIG (1983), "Bank runs, deposit insurance and liquidity", Journal of Political Economy, 91(3), pp. 401-419.

DURLAUF, S.N. and D.T. QUAH (1998), "The new empirics of economic growth", NBER Working Paper No. 6422, February.

EDEY, M. and K. HVIDING (1995), "An assessment of financial reform in OECD countries", OECD Economics Department Working Papers, No. 154.

ENGLANDER A.S. and A. GURNEY (1994), "Medium-term determinants of OECD productivity", OECD Economic Studies, No. 22, Spring, pp. 49-110.

FELDSTEIN, M. and P. BACCHETTA (1989), "National saving and international investment", NBER Working Paper, No. 3164, November.

FELDSTEIN, M. and C. HORIOKA (1980), "Domestic saving and international capital flows", Economic Journal, 90(358), June, pp. 314-29.

FERNANDEZ D.G. and A. GALETOVIC (1994), Shumpeter might be right -- but why? Explaining the relation between finance, development and growth, from School of Advanced International Studies, the Johns Hopkins University and Departamento de Ingeniería Industrial, Universidad de Chile, respectively, 14 August.

FORD, R. and P. PORET (1990), "Business investment in the OECD economies: recent performance and some implications for policy", OECD Department of Economics and Statistics Working Paper, No. 88 .

FRANKS, J.R. and W.N. TOUROUS (1996), "Lessons from a comparison of US and UK insolvency codes", in Bhandari and Weiss (eds.) Corporate Bankruptcy Economic and Legal Perspectives, Cambridge University Press, New York, pp. 450-66.

GALETOVIC, A. (1996), "Finance and growth: a synthesis and interpretation of the evidence", Banca Nazionale del Lavoro Quarterly Review, 196, pp. 59-82. 
GOERGEN, M. and L. RENNEBOOG (1999), "Strong managers and passive institutional investors in the UK", in Barca, F. and M. Becht (eds.), Ownership and Control: A European Perspective, (forthcoming).

GOLDSMITH, R. (1969), Financial Structure and Development, Yale University Press, New Haven, CT.

GREENSPAN, A. (1999), "Do efficient financial markets mitigate financial crises?" Remarks before the 1999 Financial Markets Conference of the Federal Reserve Bank of Atlanta, Sea Island, GA, 19 October.

GREENWOOD, J. and B. JOVANOVIC (1990), "Financial development, growth and the distribution of income", Journal of Political Economy, 98(5), pp. 1076-1107.

GUGLER, K., S. KALSS, A. STOMPER and J. ZECHNER (1999), "The separation of ownership and control: an Austrian perspective", in Barca, F. and M. Becht (eds.), Ownership and Control: A European Perspective, (forthcoming).

GWARTNEY, J., R. LAWSON and W. BLOCK (1996), Economic Freedom of the World, 1975-1995, Vancouver: The Fraser Institute.

HAHN, C. (2000), "Entry, exit and aggregate productivity growth: Micro evidence on Korean manufacturing", OECD Economics Department Working Papers No. 272.

HALTIWANGER, J. (2000), "Aggregate growth: What have we learned from microeconomic evidence?", OECD Economics Department Working Papers No. 267.

HARRISON, P., O. SUSSMAN and J. ZEIRA (1999), "Finance and growth: Theory and new evidence", Federal Reserve Board.

HOLMES, K.R., B.T. JOHNSON and M. KIRKPATRICK (1997), 1997 Index of Economic Freedom, Washington DC: The Heritage Foundation.

IMF (2000), International Financial Statistics, Vol. LIII, No. 1, January, Washington D.C.

JOHNSON, R. and D. WICHERN (1997), Applied Multivariate Statistical Analysis. Fourth edition, Prentice Hall.

JORGENSEN, D.W. (1967), "The theory of investment behavior", in Determinants of Investment Behavior, Universities National Bureau Conference Series, No. 18, (ed.) R. Ferber, Columbia University Press, N.Y., pp. 129-155.

KAUFMANN, D., A. KRAAY and P. ZOIDO-LOBATON (1999a), "Aggregating governance indicators", World Bank Policy Research Department Working Paper No. 2195.

KAUFMANN, D., A. KRAAY and P. ZOIDO-LOBATON (1999b), "Governance matters", World Bank Policy Research Department Working Paper No. 2196.

KING. R.G. and R. LEVINE (1993) "Finance and growth: Schumpeter might be right", Quarterly Journal of Economics, August.

KYUNG SO IM, H. PESARAN and Y. SHIN (1995-1997), "Testing for unit roots in heterogeneous panels", abstract, Indiana University, Indianapolis University, Trinity College of Cambridge, 
Department of Applied Economics, University of Cambridge, (first version June and this version December).

LA PORTA, R., F. LOPEZ-DE-SILANES, A. SHLEIFER and R.W. VISHNY (1997) "Legal determinants of external finance", Journal of Finance 52 (3), pp. 1131-1150.

LA PORTA, R., F. LOPEZ-DE-SILANES, A. SHLEIFER and R.W. VISHNY (1998) "Law and finance", Journal of Political Economy 106 (6), pp. 1113-1155.

LA PORTA, R., F. LOPEZ-DE-SILANES, A. SHLEIFER and R.W. VISHNY (1999), "The quality of government", Journal of Law, Economics, and Organization 15 (1), pp. 222-279.

LEVINE, R. (1997), "Financial development and economic growth: views and agendas", Journal of Economic Literature, Vol. XXXV, June, pp. 688-726.

LEVINE, R. (1999), "Law, finance and economic growth", Journal of Financial Intermediation, 8(1-2), January-April, pp. 8-35.

LEVINE, R. (2000), "Bank-based or market-based financial systems: which is better?" Finance Department, Carlson School of Management, University of Minnesota, mimeo, January.

LEVINE, R. and S. ZERVOS (1996), "Stock market development and long-run growth", World Bank Policy Research Working Paper, No. 1582, March.

LEVINE, R. and S. ZERVOS (1998), "Stock markets, banks, and economic growth," American Economic Review, June, pp. 537-58.

LEVINE, R., N. LOAYZA and T. BECK (2000), "Financial intermediation and growth: causality and causes", Journal of Monetary Economics 46, pp. 31-77.

LONG, M. and I. MALITZ (1985), "The investment-financing nexus: some empirical evidence", Midland Corporate Finance Journal 3, pp. 53-59.

LUINTEL, K.B. and M. KHAN (1999), "A quantitative reassessment of the finance-growth nexus: evidence from a multivariate VAR", Journal of Development Economics, Vol. 60, pp. 381-405.

MAHER, M. and T. ANDERSSON (2000), "Corporate governance: effects on firm performance and economic growth" in Renneboog, L., J. McCahery, P. Moerland and T. Raaijmakers (eds), Convergence and Diversity of Corporate Governance Regimes and Capital Markets, forthcoming, Oxford University Press.

MCKINNON, R.I. (1973), Money and Capital in Economic Development, Brookings Institution, Washington D.C.

MYLONAS, P., S. SCHICH, T. THORGEIRSSON and G. WEHINGER (2000), "New issues in public debt management: government surpluses in several OECD countries, the common currency in Europe and rapidly rising debt in Japan”, OECD Economics Department Working Papers No. 239, Paris.

NICOLETTI, G., S. SCARPETTA and O. BOYLAUD (1999), "Summary indicators of product market regulation with an extension to employment protection legislation", OECD Economics Department Working Papers No. 226, Paris. 
ECO/WKP(2001)6

OECD (1994), Employment Outlook, Paris.

OECD/Eurostat (1997), Oslo Manual, Paris.

OECD (1997a),"Regulatory reform in the financial services industry", in The OECD Report on Regulatory Reform: Volume 1: Sectoral Studies, Paris.

OECD (1997b), Economic Surveys, France, Paris.

OECD (1998a), Economic Surveys, Germany, Paris.

OECD (1998b), Economic Surveys, Japan, Paris.

OECD (1998c), Economic Surveys, Korea, Paris.

OECD (1998d), Economic Surveys, United States, Paris.

OECD (1998e), Fostering Entrepreneurship, Paris.

OECD (1999a), OECD Principles of Corporate Governance, Paris.

OECD (1999b), Science, Technology and Industry Scoreboard 1999, Benchmarking Knowledge-based Economies, Paris.

OECD (2000), A New Economy? The Changing Role of Innovation and Information Technology in Growth, Paris, forthcoming.

OECD (2001), Company Law Reform in OECD Countries: A Comparative Outlook of Current Trends (forthcoming).

PAGANO, M. (1993), "Financial markets and growth: an overview", European Economic Review 37, pp. 613-622.

PESARAN, M.H., Y. SHIN and R.P. SMITH (1996), Testing for the existence of a long-run relationship", DAE Working Paper, Department of Applied Economics University of Cambridge, Amalgamated Series, No. 9622.

PESARAN, M.H., Y. SHIN and R.P. SMITH (1998), "Pooled mean group estimation of dynamic heterogeneous panels", mimeo, revised November.

PESARAN, M.H., R.P. SMITH and T. AKIYAMA (1997), "Energy demand in Asian economies", Oxford University Press, Abstracts of Current Studies, No. 679-19C, December.

POLITICAL RISK SERVICES, International Country Risk Guide, East Syracuse, NY: Political Risk Services, Institutional Reform and Informational Sector, various years.

PORTER, M.E. and S. STERN (1999), The new challenge to America's prosperity: findings from the innovation index, Council on Competitiveness, Washington DC.

PROWSE, S. (1994), "Corporate governance in international perspective: a survey of corporate control mechanisms among large firms in the United States, the United Kingdom, Japan and Germany", BIS Economic Papers, No. 41. 
RAJAN, J. and L.ZINGALES (1998), "Financial dependence and growth", American Economic Review 88, pp. 559-586.

RAJAN, J. and L. ZINGALES (2000), "Financial systems, industrial structure and growth”, paper prepared for the Symposium of the International Competitiveness of the Swedish Financial Industry organised by the Bank of Sweden Tercentenary Foundation.

RAMEY, G. and V. A. RAMEY (1995), "Cross country evidence on the link between volatility and growth", American Economic Review, 85:5, pp. 1138-51.

REYNOLDS, P.D., M. HAY and S.M. CAMP (1999), Global Entrepreneurship Monitor, 1999 Executive Report, www.entreworld.org.

REYNOLDS, T. and A. FLORES (1998), Foreign Law: Current Sources of Basic Legislation in Jurisdictions of the World, Rothman and Co., Littleton, Colorado.

SCARPETTA, S., A. BASSANINI, D. PILAT and P. SCHREYER (2000), "Economic growth in the OECD area: recent trends at the aggregate and sectoral level", OECD Economics Department Working Papers No. 248.

SCHREYER, P. (2000), "The contribution of information and communication technologies to output growth”, OECD STI Working Papers, No. 2000/2, Paris.

SHAW, E.S. (1973), Financial Deepening in Economic Development, Oxford University Press, New York, N.Y.

SMITH, A. (1776), An Inquiry into the Nature and Causes of the Wealth of Nations, The World's Classics Series (1993, reprint edition), Oxford University Press, New York.

STIGLITZ, J. (1985), "Credit markets and the control of capital", Journal of Money, Credit and Banking, No. 17, pp. 133-152.

TEMPLE J. (1999), "The new growth evidence", Journal of Economic Literature, Vol. XXXVII, March, pp. 112-156.

TEVLIN, S. and K. WHELAN (2000), "Explaining the equipment investment boom", Draft prepared for AEA meetings, Division of Research and Statistics, Federal Reserve Board, January.

TSURU, K. (2000), "Finance and growth: some theoretical considerations, and a review of the empirical literature, OECD Economics Department Working Papers, No. 228, Paris.

WHITE, M.J. (1996), "The costs of corporate bankruptcy: a US-European comparison", in Bhandari and Weiss (eds.). Corporate Bankruptcy Economic and Legal Perspectives, Cambridge University Press, New York, pp. 467-500. 


\section{TABLES AND FIGURES}

\section{Tables}

1. Measures of investor protection

2. Framework conditions: enforcement and transparency

3. Bi-variate relationships with various measures of framework conditions

4. Correlation between gross investment and financial development measures

5. Long-run coefficient estimates from regressions of the change in gross investment in OECD countries

6. Selected empirical studies of the finance-investment link

7. Tests for robustness of pooled mean group estimates

8. Long-run coefficient estimates from regressions of the change in the investment share in OECD countries

9. Long-run coefficient estimates from regressions of the change in real per capita GDP in OECD countries

10. Estimated contribution of financial development indicators to investment and GDP per capita

\section{Figures}

1. Innovation measures and investor protection

2. Investments in innovative activity and investor protection

3. Liquid liabilities to GDP

4. Private credit by deposit money banks to GDP

5. Stock market capitalisation to GDP

6. Financial development and framework conditions: private credit and stock market capitalisation

7. Real private non-residential fixed capital formation

8. $\quad$ Coefficient estimates for different samples

9. Coefficient estimates for different time periods 
ECO/WKP(2001)6

Table 1. Measures of investor protection

(First principal components of selected groups of indicators of financial framework conditions)

\begin{tabular}{|c|c|c|c|c|c|}
\hline & $\begin{array}{c}\text { Shareholder } \\
\text { rights }\end{array}$ & Creditor rights & $\begin{array}{l}\text { Shareholder and } \\
\text { creditor rights }\end{array}$ & $\begin{array}{c}\text { Enforcement and } \\
\text { transparency }\end{array}$ & $\begin{array}{l}\text { Compound } \\
\text { measure }^{1}\end{array}$ \\
\hline United States & 1.62 & -0.88 & 1.28 & 0.21 & 0.42 \\
\hline Japan & 1.72 & 0.41 & 2.21 & -0.06 & -0.52 \\
\hline Germany & -0.36 & 0.37 & -0.59 & 0.13 & 0.23 \\
\hline France & -0.59 & 0.30 & -0.31 & -0.43 & -0.61 \\
\hline Italy & -1.48 & -0.36 & -1.54 & -1.25 & -0.95 \\
\hline United Kingdom & 0.52 & 1.66 & 0.55 & 0.76 & 0.86 \\
\hline Canada & 1.84 & -0.88 & 1.50 & 0.47 & 0.62 \\
\hline Australia & 1.20 & -0.88 & 0.95 & 0.43 & 0.60 \\
\hline Austria & -0.81 & 0.37 & -0.93 & 0.28 & 0.24 \\
\hline Belgium & -1.03 & -0.15 & -0.99 & -0.40 & -0.29 \\
\hline Denmark & -0.12 & 0.37 & -0.46 & 0.58 & 0.76 \\
\hline Finland & -0.57 & -0.88 & -0.50 & 0.76 & 0.56 \\
\hline Greece & -0.58 & 1.59 & 0.53 & -2.81 & -3.19 \\
\hline Ireland & 0.07 & -0.88 & 0.04 & -0.32 & -0.22 \\
\hline Netherlands & -1.03 & -0.36 & -1.10 & 0.71 & 0.53 \\
\hline New Zealand & 1.20 & 2.84 & 1.30 & 0.71 & 0.66 \\
\hline Norway & -0.12 & -0.36 & -0.42 & 0.94 & 1.02 \\
\hline Portugal & -0.35 & -0.88 & -0.29 & -1.65 & -1.28 \\
\hline Spain & 0.48 & -0.15 & 0.41 & -1.12 & -0.96 \\
\hline Sweden & -0.57 & -0.36 & -0.76 & 0.88 & 0.82 \\
\hline Switzerland & -1.03 & -0.88 & -0.85 & 1.18 & 0.72 \\
\hline \multicolumn{6}{|l|}{ Means: ${ }^{2}$} \\
\hline G7 & 0.47 & 0.09 & 0.44 & -0.03 & 0.01 \\
\hline EU & -0.46 & 0.05 & -0.43 & -0.28 & -0.25 \\
\hline Euro 11 & -0.57 & -0.26 & -0.58 & -0.33 & -0.28 \\
\hline
\end{tabular}

1. This measure of investor protection is the first principal component of the collective set of financial framework conditions: enforcement, transparency, shareholder and creditor rights.

2. The values are scaled to have an overall mean of zero and standard deviation of one. The means for each sub-group below are averages of respective countries in the sample only.

Source: OECD calculations based on a variety of indicators of financial framework conditions prior to 1998 . See appendix for details on data. 
ECO/WKP(2001)6

Table 2. Framework conditions: enforcement and transparency

\begin{tabular}{|c|c|c|c|c|c|c|}
\hline \multirow[t]{2}{*}{ Country } & \multicolumn{2}{|c|}{ Observance of laws and regulations } & \multirow{2}{*}{$\begin{array}{l}\text { Efficiency of } \\
\text { judicial system } \\
\text { (a) }\end{array}$} & \multirow{2}{*}{$\begin{array}{c}\text { Policy } \\
\text { effectiveness } \\
\text { (b) }\end{array}$} & \multirow{2}{*}{$\begin{array}{l}\text { Risk of contract } \\
\text { repudiation } \\
\text { (a) }\end{array}$} & \multirow{2}{*}{$\begin{array}{l}\text { Rating on } \\
\text { accounting } \\
\text { standards } \\
\text { (c) }\end{array}$} \\
\hline & (a) & (b) & & & & \\
\hline United States & 10.00 & 7.51 & 10.00 & 7.73 & 9.00 & 71 \\
\hline Japan & 8.98 & 7.84 & 10.00 & 6.68 & 9.69 & 65 \\
\hline Germany & 9.23 & 7.97 & 9.00 & 7.82 & 9.77 & 62 \\
\hline France & 8.98 & 7.15 & 8.00 & 7.56 & 9.19 & 69 \\
\hline Italy & 8.33 & 6.72 & 6.75 & 6.55 & 9.17 & 62 \\
\hline United Kingdom & 8.57 & 8.38 & 10.00 & 8.93 & 9.63 & 78 \\
\hline Canada & 10.00 & 8.10 & 9.25 & 8.43 & 8.96 & 74 \\
\hline Australia & 10.00 & 8.19 & 10.00 & 7.92 & 8.71 & 75 \\
\hline Austria & 10.00 & 8.62 & 9.50 & 7.44 & 9.60 & 54 \\
\hline Belgium & 10.00 & 6.59 & 9.50 & 6.77 & 9.48 & 61 \\
\hline Denmark & 10.00 & 8.38 & 10.00 & 8.44 & 9.31 & 62 \\
\hline Finland & 10.00 & 8.47 & 10.00 & 8.27 & 9.15 & 77 \\
\hline Greece & 6.18 & 5.99 & 7.00 & 6.12 & 6.62 & 55 \\
\hline Ireland & 7.80 & 7.79 & 8.75 & 7.72 & 8.96 & $74^{1}$ \\
\hline Netherlands & 10.00 & 8.17 & 10.00 & 9.06 & 9.35 & 64 \\
\hline New Zealand & 10.00 & 8.65 & 10.00 & 8.14 & 9.29 & 70 \\
\hline Norway & 10.00 & 8.67 & 10.00 & 8.33 & 9.71 & 74 \\
\hline Portugal & 8.68 & 7.17 & 5.50 & 7.30 & 8.57 & 36 \\
\hline Spain & 7.80 & 7.06 & 6.25 & 8.21 & 8.40 & 64 \\
\hline Sweden & 10.00 & 8.25 & 10.00 & 8.15 & 9.58 & 83 \\
\hline Switzerland & 10.00 & 8.99 & 10.00 & 8.97 & 9.98 & 68 \\
\hline \multicolumn{7}{|l|}{ Means: } \\
\hline Overall & 9.26 & 7.84 & 9.02 & 7.84 & 9.15 & 67 \\
\hline $\mathrm{G} 7^{2}$ & 9.16 & 7.67 & 9.00 & 7.67 & 9.34 & 69 \\
\hline$E U^{2}$ & 8.97 & 7.62 & 8.59 & 7.74 & 9.06 & 64 \\
\hline Euro $11^{2}$ & 9.08 & 7.57 & 8.33 & 7.67 & 9.16 & 62 \\
\hline
\end{tabular}

1. For Ireland, "Rating on accounting standards" is based on industrial companies only.

2. Countries in sample.

Note: See the appendix for variable definitions and dates of assessments. Higher scores indicate stronger contract and law enforcement and greater transparency. Scores can range from zero to 10 for enforcement and zero to 100 for the rating on account standards. Data are available for a broader range of countries, but only those used in the estimation are reported here.

Sources: (a) La Porta et al. (1998); (b) Kaufmann et al. (1999a,b); and (c) CIFAR (1995). See appendix for details on description and timing of individual indicators, which vary in their period of observation from 1980 to 1998. 
Table 3. Bi-variate relationships with various measures of framework conditions

(Correlation coefficients and $\mathrm{p}$-values)

\begin{tabular}{|c|c|c|c|c|c|c|c|c|c|c|}
\hline \multirow{3}{*}{ Dependent variable } & \multicolumn{10}{|c|}{ First principal component of } \\
\hline & \multicolumn{2}{|c|}{ Shareholder rights } & \multicolumn{2}{|c|}{ Creditor rights } & \multicolumn{2}{|c|}{$\begin{array}{l}\text { Shareholder and } \\
\text { creditor rights }\end{array}$} & \multicolumn{2}{|c|}{$\begin{array}{l}\text { Enforcement and } \\
\text { transparency }\end{array}$} & \multicolumn{2}{|c|}{$\begin{array}{l}\text { Enforcement, } \\
\text { shareholder and } \\
\text { creditor rights }\end{array}$} \\
\hline & Coefficient & $p$-value & Coefficient & $p$-value & Coefficient & $p$-value & Coefficient & $p$-value & Coefficient & $p$-value \\
\hline $\begin{array}{l}\text { R\&D expenditure in per cent of GDP } \\
\text { (average 1990-97) }\end{array}$ & 0.08 & 0.741 & -0.22 & 0.349 & 0.00 & 0.990 & 0.65 & 0.001 & 0.56 & 0.009 \\
\hline $\begin{array}{l}\text { Total R\&D personnel per thousand labour force } \\
\text { (average 1990-97) }\end{array}$ & 0.00 & 0.999 & -0.19 & 0.414 & -0.06 & 0.797 & 0.68 & 0.001 & 0.57 & 0.009 \\
\hline $\begin{array}{l}\text { Resident patent applications per } 10000 \text { population } \\
\quad(\text { average } 1990-97)^{1}\end{array}$ & 0.16 & 0.515 & -0.04 & 0.871 & 0.05 & 0.846 & 0.69 & 0.001 & 0.65 & 0.002 \\
\hline $\begin{array}{l}\text { Patents in the United States, per } 100000 \text { population } \\
\quad(\text { average 1990-97) }\end{array}$ & -0.07 & 0.769 & -0.20 & 0.429 & -0.24 & 0.340 & 0.62 & 0.006 & 0.57 & 0.013 \\
\hline $\begin{array}{l}\text { IPOs per million of population, } \\
(1995: 7-1996: 6)\end{array}$ & 0.48 & 0.039 & -0.26 & 0.291 & 0.30 & 0.217 & 0.45 & 0.052 & 0.50 & 0.028 \\
\hline $\begin{array}{l}\text { Venture capital investment, early stage and } \\
\text { expansion, in per cent of GDP (average 1995-98) }\end{array}$ & 0.19 & 0.459 & -0.26 & 0.289 & 0.05 & 0.839 & 0.44 & 0.067 & 0.47 & 0.049 \\
\hline $\begin{array}{l}\text { Private non-residential fixed capital formation in per } \\
\text { cent of GDP (average 1990-95) }\end{array}$ & -0.03 & 0.894 & -0.15 & 0.532 & -0.02 & 0.937 & 0.10 & 0.662 & 0.04 & 0.874 \\
\hline $\begin{array}{l}\text { Log real GDP per capita, at } 1995 \text { US\$ PPP } \\
\text { (average 1990-95) }\end{array}$ & 0.11 & 0.636 & -0.34 & 0.135 & -0.05 & 0.830 & 0.67 & 0.001 & 0.64 & 0.002 \\
\hline $\begin{array}{l}\text { GDP growth } \\
\text { (average 1990-95) }\end{array}$ & 0.20 & 0.392 & -0.05 & 0.833 & 0.10 & 0.675 & -0.01 & 0.953 & 0.07 & 0.754 \\
\hline $\begin{array}{l}\text { Change in GDP growth } \\
\text { (average 1990s minus average 1980s) }\end{array}$ & -0.08 & 0.747 & -0.01 & 0.951 & -0.16 & 0.503 & -0.10 & 0.675 & -0.01 & 0.965 \\
\hline $\begin{array}{l}\text { MFP growth corrected for hours worked } \\
\text { (average 1990-98) }\end{array}$ & 0.02 & 0.916 & -0.36 & 0.112 & -0.05 & 0.835 & 0.21 & 0.366 & 0.23 & 0.318 \\
\hline $\begin{array}{l}\text { Change in MFP growth corrected for hours worked } \\
\text { (average 1990s minus average 1980s) }\end{array}$ & 0.26 & 0.272 & -0.19 & 0.428 & 0.15 & 0.532 & 0.47 & 0.035 & 0.48 & 0.033 \\
\hline
\end{tabular}

1. Excluding Japan.

2. US patents granted to residents of foreign countries, excluding Japan and Switzerland.

3. Data for Japan and Australia are for 1994 and 1997, respectively.

Note: Variables from which principal components are calculated are defined in the appendix.

Source: OECD calculations. 
ECO/WKP(2001)6

Table 4. Correlation between gross investment and financial development measures

(1970-97 for LILI and PCD, 1976-97 for SMC)

\begin{tabular}{|c|c|c|c|}
\hline & (i) Liquid liabilities (LILI) & $\begin{array}{l}\text { (ii) Private credit of deposit money } \\
\text { banks (PCD) }\end{array}$ & $\begin{array}{l}\text { (iii) Stock market capitalisation } \\
\text { (SMC) }\end{array}$ \\
\hline Australia & $0.94^{\star *}$ & $0.91^{* *}$ & $0.87^{\star \star}$ \\
\hline Austria & $0.88^{* *}$ & $0.90^{* *}$ & $0.92^{* *}$ \\
\hline Belgium & $0.73^{\star *}$ & $0.83^{* *}$ & $0.92^{* *}$ \\
\hline Canada & $0.90^{* *}$ & $0.95^{\star *}$ & $0.92^{* *}$ \\
\hline Denmark & $0.86^{\star *}$ & -0.10 & $0.88^{* *}$ \\
\hline Finland & -0.23 & -0.02 & -0.28 \\
\hline France & 0.08 & $0.86^{\star *}$ & $0.94^{* *}$ \\
\hline Germany & $0.73^{\star *}$ & $0.85^{\star *}$ & $0.76^{\star \star}$ \\
\hline Greece & 0.32 & -0.34 & 0.36 \\
\hline Italy & $-0.77^{* *}$ & $-0.57^{\star *}$ & $0.76^{* *}$ \\
\hline Japan & $0.93^{* *}$ & $0.97^{\star *}$ & $0.86^{* *}$ \\
\hline Netherlands & $0.54^{* *}$ & $0.80^{\star \star}$ & $0.92^{* *}$ \\
\hline Norway & $-0.38^{*}$ & 0.19 & 0.04 \\
\hline New Zealand & $0.46^{*}$ & $0.83^{* *}$ & 0.70 \\
\hline Spain & 0.27 & $0.62^{\star \star}$ & $0.87^{\star \star}$ \\
\hline Sweden & $-0.81^{* *}$ & $0.31^{* *}$ & 0.70 \\
\hline Switzerland & $0.78^{* *}$ & $0.92^{* *}$ & $0.79^{\star \star}$ \\
\hline United Kingdom & $0.93^{* *}$ & $0.96^{\star \star}$ & $0.96^{\star \star}$ \\
\hline United States & -0.21 & $0.66^{\star \star}$ & $0.91^{* *}$ \\
\hline OECD & $0.40^{* *}$ & $0.22^{* *}$ & $-0.23^{* *}$ \\
\hline
\end{tabular}

Key: $\quad{ }^{* *}$ and ${ }^{*}=$ correlation is significant at the 1 per cent and 5 per cent levels, respectively.

Source: OECD estimates. 
Table 5. Long-run coefficient estimates from regressions of the change in gross investment in OECD countries

\begin{tabular}{|c|c|c|c|c|c|c|c|c|c|c|c|c|}
\hline \multirow[b]{2}{*}{ Estimators $^{1}$} & \multicolumn{4}{|c|}{ (i) Liquid liabilities (LILI) } & \multicolumn{4}{|c|}{ (ii) Private credit of deposit money banks (PCD) } & \multicolumn{4}{|c|}{ (iii) Stock market capitalisation (SMC) } \\
\hline & SFE & DFE & PMG & MGE & SFE & DFE & PMG & MGE & SFE & DFE & PMG & MGE \\
\hline Financial development ${ }^{2}$ & $\begin{array}{c}0.16 \\
(0.08)^{*}\end{array}$ & $\begin{array}{c}0.14 \\
(0.11)\end{array}$ & $\begin{array}{l}0.21 \\
(0.05)^{*}\end{array}$ & $\begin{array}{c}0.25 \\
(0.37)\end{array}$ & $\begin{array}{l}0.11 \\
(0.04)^{\star *}\end{array}$ & $\begin{array}{c}0.02 \\
(0.09)\end{array}$ & $\begin{array}{c}0.08 \\
(0.02)^{\star *}\end{array}$ & $\begin{array}{l}-0.02 \\
(0.18)\end{array}$ & $\begin{array}{c}0.04 \\
(0.02)^{\star}\end{array}$ & $\begin{array}{l}0.10 \\
(0.03)^{\star \star}\end{array}$ & $\begin{array}{l}0.17 \\
(0.01)^{\star *}\end{array}$ & $\begin{array}{l}0.14 \\
(0.07)^{\star \star}\end{array}$ \\
\hline Gross domestic product & $\begin{array}{c}1.16 \\
(0.11)^{* *}\end{array}$ & $\begin{array}{c}1.24 \\
(0.11)^{\star *}\end{array}$ & $\begin{array}{c}1.65 \\
(0.07)^{\star \star}\end{array}$ & $\begin{array}{c}1.33 \\
(0.20)^{* *}\end{array}$ & $\begin{array}{l}1.14 \\
(0.11)^{\star \star}\end{array}$ & $\begin{array}{c}1.29 \\
(0.12)^{\star *}\end{array}$ & $\begin{array}{c}1.58 \\
(0.04)^{\star \star}\end{array}$ & $\begin{array}{c}1.39 \\
(0.25)^{\star \star}\end{array}$ & $\begin{array}{l}1.41 \\
(0.06)^{\star *}\end{array}$ & $\begin{array}{c}1.25 \\
(0.10)^{\star \star}\end{array}$ & $\begin{array}{c}1.30 \\
(0.03)^{\star *}\end{array}$ & $\begin{array}{c}1.41 \\
(0.24)^{\star *}\end{array}$ \\
\hline Adjusted real interest rate & $\begin{array}{l}-0.55 \\
(0.44)\end{array}$ & $\begin{array}{l}-0.03 \\
(0.59)\end{array}$ & $\begin{array}{l}0.96 \\
(0.22)^{\star *}\end{array}$ & $\begin{array}{l}-0.39 \\
(0.61)\end{array}$ & $\begin{array}{l}-0.66 \\
(0.40)\end{array}$ & $\begin{array}{l}-0.04 \\
(0.56)\end{array}$ & $\begin{array}{l}-0.49 \\
(0.19)^{*}\end{array}$ & $\begin{array}{l}-0.39 \\
(0.58)\end{array}$ & $\begin{array}{l}-0.48 \\
(0.24)^{*}\end{array}$ & $\begin{array}{l}-0.38 \\
(0.30)\end{array}$ & $\begin{array}{c}0.03 \\
(0.17)\end{array}$ & $\begin{array}{l}-0.96 \\
(0.97)\end{array}$ \\
\hline $\begin{array}{l}\text { Memorandum items: } \\
\text { Average error correction } \\
\text { coefficient }\end{array}$ & & $\begin{array}{l}-0.25 \\
(0.05)^{\star *}\end{array}$ & $\begin{array}{l}-0.26 \\
(0.05)^{\star \star}\end{array}$ & $\begin{array}{l}-0.46 \\
(0.06)^{\star \star}\end{array}$ & & $\begin{array}{l}-0.25 \\
(0.05)^{\star *}\end{array}$ & $\begin{array}{l}-0.37 \\
(0.06)^{\star \star}\end{array}$ & $\begin{array}{l}-0.50 \\
(0.07)^{\star \star}\end{array}$ & & $\begin{array}{l}-0.47 \\
(0.03)^{\star \star}\end{array}$ & $\begin{array}{l}-0.30 \\
(0.06)^{\star *}\end{array}$ & $\begin{array}{l}-0.41 \\
(0.05)^{\star \star}\end{array}$ \\
\hline Joint Hausman test ${ }^{3}$ & & & $\begin{array}{l}15.62 \\
{[0.00]}\end{array}$ & & & & $\begin{array}{c}2.82 \\
{[0.42]}\end{array}$ & & & & $\begin{array}{c}1.21 \\
{[0.75]}\end{array}$ & \\
\hline
\end{tabular}

1. All techniques are variations of an error correction approach (see the appendix). SFE is the static fixed effects estimator; the functional form imposes a unit coefficient for the error correction term. DFE is the dynamic fixed effects model, where a general ARDL $(2,0,0,0)$ specification is chosen. That is, an autoregressive distributed lag model with two lags on the lagged dependent and no lags on the first difference in the three regressors. Standard errors for SFE and DFE are adjusted for heteroscedasticity (White). PMG is the pooled mean group estimator. MGE is the mean group estimator, obtained as the unweighted mean of the country specific estimates of the coefficients. The lag orders for the short-run adjustment variables in the cases of PMG and MGE are chosen according to the Schwarz Bayesian criterion, where the maximum lag is set equal to two.

2. Financial development is proxied by: (i) liquid liabilities; (ii) private credit of deposit money banks; or (iii) stock market capitalisation.

3. The joint Hausman test is the test for long-run slope homogeneity, with p-values shown in square brackets.

Notes: Rounded standard errors are shown in parentheses. ${ }^{*}$ and ${ }^{\star \star}$ indicate significance at the 5 per cent and the 1 per cent levels, respectively.

Data are for 19 countries from 1970 to 1997 in the case of liquid liabilities and private credit and for 16 countries (excluding Finland, Norway and New Zealand) from 1976 to 1997 for stock market capitalisation. All variables in logarithms. The real interest rate $r$ enters as $\log (1+r)$.

Sources: Data on financial development from the World Bank; other data from OECD. 
Table 6. Selected empirical studies of the finance-investment link ${ }^{1}$

\begin{tabular}{|c|c|c|c|}
\hline \multirow{2}{*}{ Author } & \multirow{2}{*}{$\begin{array}{l}\text { Sample and } \\
\text { method }\end{array}$} & \multicolumn{2}{|r|}{ Results and Comments } \\
\hline & & Overall & OECD countries \\
\hline $\begin{array}{l}\text { King and Levine } \\
\text { (1993) }\end{array}$ & $\begin{array}{l}80 \text { countries } \\
1960-1989\end{array}$ & $\begin{array}{l}\text { CAP and INV are positively and } \\
\text { highly significantly related to } \\
\text { contemporaneous and lagged } \\
\text { LILI and CREDIT. }\end{array}$ & $\begin{array}{l}\text { The exclusion of OECD countries from the sample does } \\
\text { not affect the significance of their results. }\end{array}$ \\
\hline $\begin{array}{l}\text { Fernandez and } \\
\text { Galetovic (1994) }\end{array}$ & $\begin{array}{l}79 \text { countries } \\
1960-89\end{array}$ & $\begin{array}{l}\text { LILI strong positively correlated } \\
\text { with INV. }\end{array}$ & $\begin{array}{l}\text { Correlation for OECD sub-sample considerably weaker } \\
\text { than for the wider sample and statistically insignificant. }\end{array}$ \\
\hline $\begin{array}{l}\text { De Gregorio and } \\
\text { Guidotti (1995) }\end{array}$ & $\begin{array}{l}98 \text { countries } \\
1960-85\end{array}$ & $\begin{array}{l}\text { CREDIT significant positively } \\
\text { correlated with GDP, and its } \\
\text { coefficient increases only little } \\
\text { when INV is not included as } \\
\text { regressor. Thus, CREDIT } \\
\text { contributes to GDP in that it } \\
\text { improves the efficiency of INV } \\
\text { rather than its volume. This is } \\
\text { confirmed by a regression of } \\
\text { the same variables on INV. }\end{array}$ & $\begin{array}{l}\text { No significant effect of CREDIT on the efficiency of INV } \\
\text { for a sub-sample of } 31 \text { high-income countries. By } \\
\text { contrast, the effect on the volume of INV appears to be } \\
\text { non-negligible and somewhat stronger for OECD } \\
\text { countries than for the remainder of the sample (that is, } \\
\text { low and middle-income countries). }\end{array}$ \\
\hline $\begin{array}{l}\text { Levine and Zervos } \\
\text { (1998) }\end{array}$ & $\begin{array}{l}47 \text { countries } \\
1976-93\end{array}$ & $\begin{array}{l}\text { CREDIT as well as SMC } \\
\text { significantly positively } \\
\text { correlated with CAP. }\end{array}$ & \\
\hline $\begin{array}{l}\text { Black and Moersch } \\
\text { (1998) }\end{array}$ & $\begin{array}{l}24 \text { countries } \\
1965-92\end{array}$ & & $\begin{array}{l}\text { CREDIT but not SMC is significant in the regression on } \\
\text { INV using the full sample of OECD countries. } \\
\text { Distinguishing between types of financial systems, on } \\
\text { the one hand CREDIT is strongly significant for } \\
\text { countries with bank-based systems (Germany, } \\
\text { Switzerland, Austria, Japan), while SMC is not. On the } \\
\text { other, SMC is significant for countries with market- } \\
\text { based system (United States, United Kingdom, } \\
\text { Australia, Canada), while the bank credit is not. In the } \\
\text { remaining countries neither variable is significant. } \\
\text { Validity of pooling is rejected for group of market-based } \\
\text { systems. }\end{array}$ \\
\hline
\end{tabular}

1. Selected studies that use either investment or capital accumulation as dependent variable (or control for investment in a growth regression).

Key: CAP - Growth rate of the real per capita physical stock; INV - Ratio of investment to GDP; GDP - Growth rate of real per capita GDP; LILI - some measures of liquid liabilities or of monetary aggregates; CREDIT - some measures of private credit; SMC - some measure of stock market capitalisation, e.g. relative to GDP or to stock market turnover.

Source: OECD, based on studies listed in the first column. 
ECO/WKP(2001)6

Table 7. Tests for robustness of pooled mean group estimates

\begin{tabular}{|c|c|c|c|c|c|}
\hline Model $^{1}$ & 1 & 2 & 3 & 4 & 5 \\
\hline Gross domestic product & $\begin{array}{l}1.27 \\
(0.05)^{\star \star}\end{array}$ & $\begin{array}{l}1.45 \\
(0.07)^{\star *}\end{array}$ & $\begin{array}{l}1.47 \\
(0.06)^{\star *}\end{array}$ & $\begin{array}{l}1.29 \\
(0.05)^{\star *}\end{array}$ & $\begin{array}{l}1.53 \\
(0.05)^{\star *}\end{array}$ \\
\hline Adjusted real interest rate & $\begin{array}{l}-0.38 \\
(0.20)\end{array}$ & $\begin{array}{l}-0.41 \\
(0.20)^{*}\end{array}$ & $\begin{array}{l}-0.38 \\
(0.27)\end{array}$ & $\begin{array}{c}0.28 \\
(0.24)\end{array}$ & $\begin{array}{l}-0.70 \\
(0.22)^{\star *}\end{array}$ \\
\hline Liquid liabilities & $\begin{array}{c}0.04 \\
(0.03)\end{array}$ & & & & \\
\hline $\begin{array}{l}\text { Private credit of deposit } \\
\text { money banks }\end{array}$ & & $\begin{array}{c}0.05 \\
(0.02)^{*}\end{array}$ & & & \\
\hline Stock market capitalisation & $\begin{array}{l}0.16 \\
(0.01)^{\star \star}\end{array}$ & $\begin{array}{l}0.10 \\
(0.02)^{\star \star}\end{array}$ & & & \\
\hline First principal component ${ }^{2}$ & & & $\begin{array}{l}0.05 \\
(0.01)^{\star *}\end{array}$ & $\begin{array}{l}0.17 \\
(0.02)^{\star \star}\end{array}$ & $\begin{array}{l}0.04 \\
(0.00)^{\star *}\end{array}$ \\
\hline $\begin{array}{l}\text { Average error correction } \\
\text { coefficient }\end{array}$ & $\begin{array}{l}-0.35 \\
(0.06)^{\star *}\end{array}$ & $\begin{array}{l}-0.39 \\
(0.07)^{\star *}\end{array}$ & $\begin{array}{l}-0.31 \\
(0.12)^{\star *}\end{array}$ & $\begin{array}{l}-0.29 \\
(0.06)^{\star *}\end{array}$ & $\begin{array}{l}-0.28 \\
(0.04)^{\star *}\end{array}$ \\
\hline Joint Hausman test ${ }^{3}$ & $\begin{array}{c}2.30 \\
{[0.68]}\end{array}$ & $\begin{array}{c}5.61 \\
{[0.23]}\end{array}$ & $\begin{array}{c}6.93 \\
{[0.07]}\end{array}$ & $\begin{array}{c}3.43 \\
{[0.33]}\end{array}$ & $\begin{array}{c}0.87 \\
{[0.83]}\end{array}$ \\
\hline
\end{tabular}

1. Models $1,2,3,4$ and 5 are respectively based on an $\operatorname{ARDL}(2,1,1,1,1)$ specification, an $\operatorname{ARDL}(2,1,1,1,1)$ specification, an $\operatorname{ARDL}(2,0,0,0)$ specification, Schwarz Bayesian criterion (where the maximum lag is set equal to two and an $\operatorname{ARDL}(2,1,1,1)$ specification.

2. First principal component of (i) liquid liabilities, (ii) private credit of deposit money banks and (iii) stock market capitalisation (Model 3), (i) private credit of deposit money banks and (ii) stock market capitalisation (Model 4) and (i) liquid liabilities and (ii) private credit of deposit money banks (Model 5).

3. The joint Hausman test is the test for long-run slope homogeneity, with p-values shown in square brackets.

Notes: $\quad$ All variables in logarithms. Rounded standard errors are shown in parentheses. * and ** indicate significance at the 5 per cent and the 1 per cent levels, respectively. Data are from 1970 to 1997 in the case of liquid liabilities, private credit and the first principal component in Model 5 and from 1976 to 1997 in models 1 and 2, for stock market capitalisation and the first principal component in Models 3 and 4.

Sources: Data on financial development from World Bank; other data from OECD. 
ECO/WKP(2001)6

\section{Table 8. Long-run coefficient estimates from regressions of the change in the investment share in OECD countries}

(Pooled mean group estimators)

\begin{tabular}{|c|c|c|c|c|}
\hline \multirow[b]{2}{*}{ Financial development ${ }^{1}$} & \multicolumn{2}{|c|}{$\begin{array}{l}\text { (i) Private credit of deposit money } \\
\text { banks (PCD) }\end{array}$} & \multicolumn{2}{|c|}{$\begin{array}{c}\text { (ii) Stock market capitalisation } \\
\text { (SMC) }\end{array}$} \\
\hline & $\begin{array}{l}0.09 \\
(0.03)^{*}\end{array}$ & $\begin{array}{l}0.06 \\
(0.04)\end{array}$ & $\begin{array}{l}0.17 \\
(0.02)^{* *}\end{array}$ & $\begin{array}{l}0.14 \\
(0.01)^{\star *}\end{array}$ \\
\hline Inflation & $\begin{array}{l}-0.02 \\
(0.01)^{* *}\end{array}$ & $\begin{array}{l}-0.03 \\
(0.00)^{\star *}\end{array}$ & $\begin{array}{l}-0.03 \\
(0.01)^{* *}\end{array}$ & $\begin{array}{l}-0.02 \\
(0.00)^{\star *}\end{array}$ \\
\hline Standard deviation of inflation & $\begin{array}{l}-0.02 \\
(0.01)\end{array}$ & $\begin{array}{l}-0.01 \\
(0.01)\end{array}$ & & \\
\hline Government capital formation & $\begin{array}{l}-0.21 \\
(0.06)^{* *}\end{array}$ & $\begin{array}{l}-0.11 \\
(0.04)^{*}\end{array}$ & $\begin{array}{l}-0.05 \\
(0.03)\end{array}$ & $\begin{array}{c}0.02 \\
(0.03)\end{array}$ \\
\hline Government consumption & $\begin{array}{l}-0.26 \\
(0.15)\end{array}$ & & & $\begin{array}{l}-0.71 \\
(0.14)^{\star \star}\end{array}$ \\
\hline Government tax receipts & & $\begin{array}{l}-0.77 \\
(0.12)^{\star *}\end{array}$ & $\begin{array}{l}-0.36 \\
(0.14)^{\star}\end{array}$ & \\
\hline Adjusted trade exposure & $\begin{array}{l}-0.32 \\
(0.12)^{* *}\end{array}$ & $\begin{array}{l}-0.05 \\
(0.08)\end{array}$ & $\begin{array}{l}-0.31 \\
(0.09)^{* *}\end{array}$ & $\begin{array}{c}0.05 \\
(0.10)\end{array}$ \\
\hline $\begin{array}{l}\text { Memorandum item: } \\
\text { Average error correction coefficient }\end{array}$ & $\begin{array}{l}-0.15 \\
(0.03)^{\star *}\end{array}$ & $\begin{array}{l}-0.22 \\
(0.05)^{\star *}\end{array}$ & $\begin{array}{l}-0.26 \\
(0.05)^{\star *}\end{array}$ & $\begin{array}{l}-0.27 \\
(0.07)\end{array}$ \\
\hline
\end{tabular}

1. Financial development is proxied by (i) private credit of deposit money banks or (ii) stock market capitalisation.

Notes: These results are taken from Table 7 of Bassanini, Scarpetta and Hemmings (2001), which also contains details on variable definitions and sample coverage. All variables in logarithms. Rounded standard errors are shown in parentheses. ${ }^{*}$ and ${ }^{* *}$ indicate significance at the 5 per cent and 1 per cent levels respectively.

Sources: Data on financial development from the World Bank; other data from OECD. 
ECO/WKP(2001)6

Table 9. Long-run coefficient estimates from regressions of the change in real per capita GDP in OECD countries

(Pooled mean group estimators)

(i) Private credit of deposit money banks (PCD)

(ii) Stock market capitalisation (SMC)

Financial development ${ }^{1}$

0.04

$(0.02)^{*}$

0.09

$(0.01)^{\star *}$

Investment share

0.30

0.14

$(0.06)^{* *}$

$(0.02)^{\star \star}$

Human capital

0.99

0.93

$(0.14)^{\star *}$

$(0.15)^{\star *}$

Change in population

$-11.54$

$(1.77)^{\star *}$

$-4.80$

$-0.02$

Standard deviation of inflation

$(0.00)^{\text {** }}$

Memorandum item:

Average error correction coefficient

$-0.13$

$-0.22$

$(0.02)^{\star *}$

$(0.05)^{\star *}$

1. Financial development is proxied by: (i) private credit of deposit money banks or (ii) stock market capitalisation.

Notes: $\quad$ These results are taken from Table 6 of Bassanini, Scarpetta and Hemmings (2001), which also contains details on variable definitions and sample coverage. All variables in logarithms. Rounded standard errors are shown in parentheses. * and ** indicate significance at the 5 per cent and 1 per cent levels respectively..

Sources: Data on financial development from the World Bank; other data from OECD. 


\section{Table 10. Estimated contribution of financial development indicators to investment and GDP per capita}

(One percentage point increase in financial development indicators)

\begin{tabular}{|c|c|c|c|c|c|c|}
\hline \multirow{4}{*}{$\begin{array}{l} \\
\text { Private credit of deposit } \\
\text { money banks }\end{array}$} & \multicolumn{4}{|c|}{$\begin{array}{l}\text { Estimated contribution of increase of one percentage point in } \\
\text { financial development indicators to: }\end{array}$} & \multirow{2}{*}{\multicolumn{2}{|c|}{ Memorandum items: ${ }^{4}$}} \\
\hline & \multirow{2}{*}{$\begin{array}{c}\text { Investment }^{1} \\
\text { (percentage point } \\
\text { change) }\end{array}$} & \multicolumn{3}{|c|}{ GDP per capita (per cent change) } & & \\
\hline & & $\begin{array}{c}\begin{array}{l}\text { Investment } \\
\text { channel }^{2}\end{array} \\
\end{array}$ & $\begin{array}{c}\text { Other } \\
\text { channels }^{3}\end{array}$ & Total & $\begin{array}{c}\text { Sample } \\
\text { mean }\end{array}$ & $\begin{array}{l}\text { Range } \\
\text { in } 1997\end{array}$ \\
\hline & 0.02 & 0.05 & 0.07 & 0.11 & 0.59 & $0.22-1.67$ \\
\hline Stock market capitalisation & 0.06 & 0.07 & 0.26 & 0.33 & 0.35 & $0.17-1.53$ \\
\hline
\end{tabular}

1. Based on estimates reported in Table 5. Mean value of investment share is 0.12 .

2. Based on estimates reported in Tables 5 and 8.

3. Based on estimates reported in Table 8.

4. For sample of OECD countries used in the estimation.

Note: All variables except GDP per capita are expressed as a share of GDP. Percentage point changes are evaluated at variable means. Detail may not sum to totals due to rounding. 
Figure 1 : Innovation measures and investor protection

R\&D expenditure in per cent of GDP (average 1990-1997)

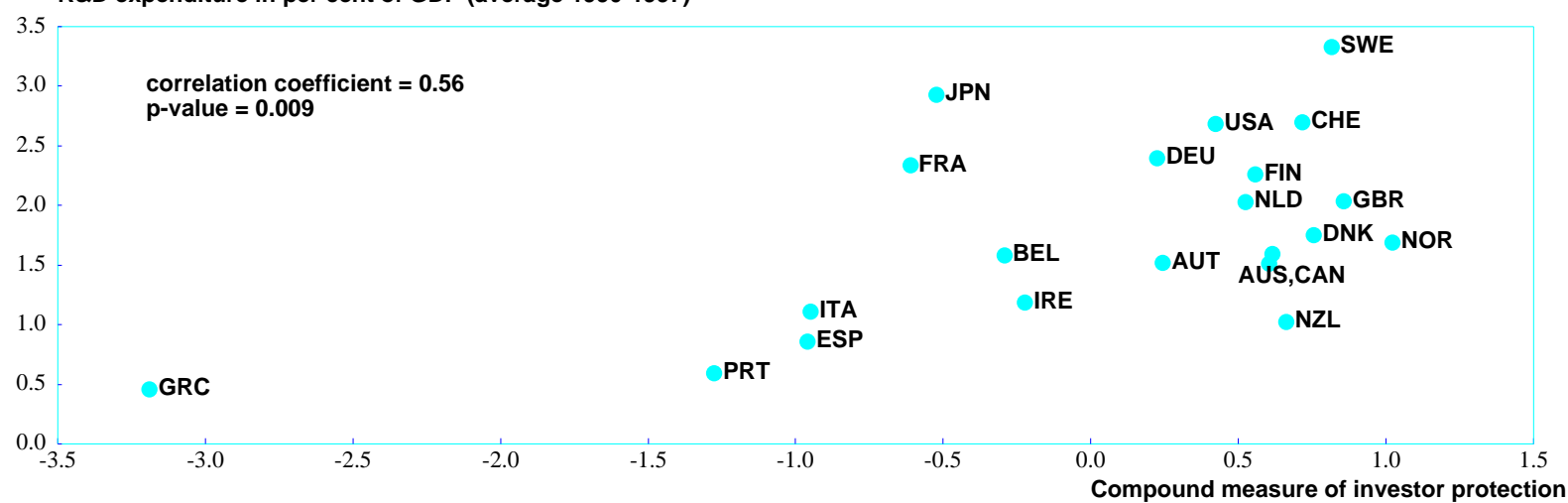

Total R\&D personnel per thousand labour force (average 1990-1997)

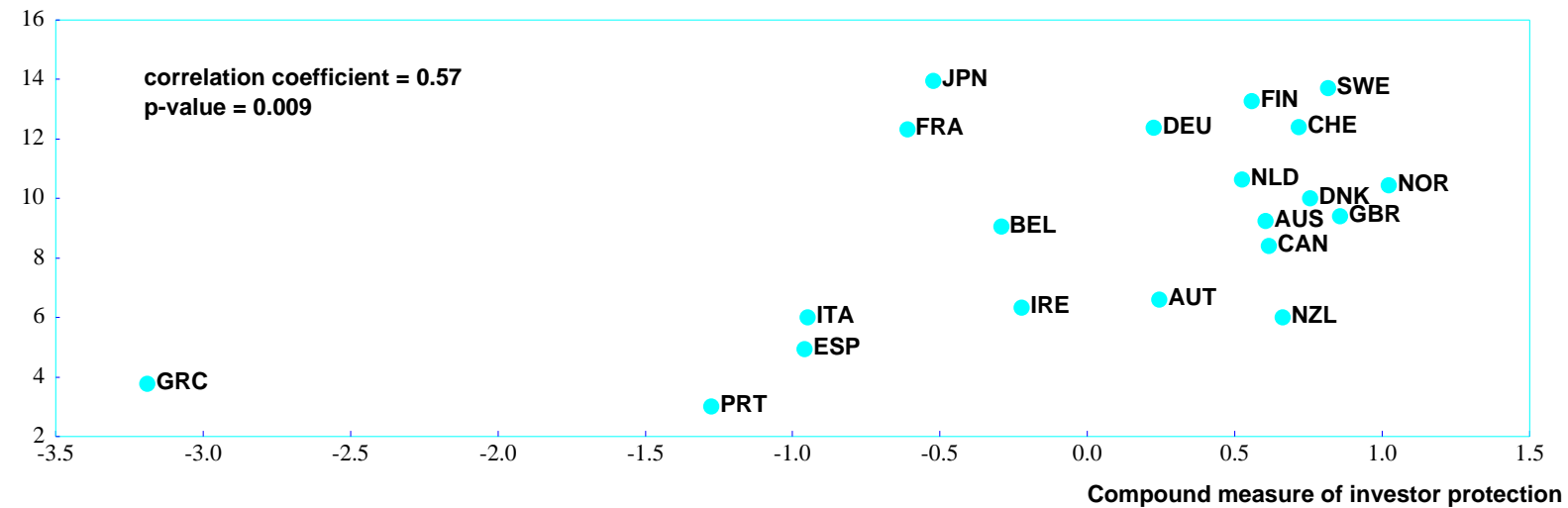

Resident patent applications per 10000 population (average 1990-1997) *

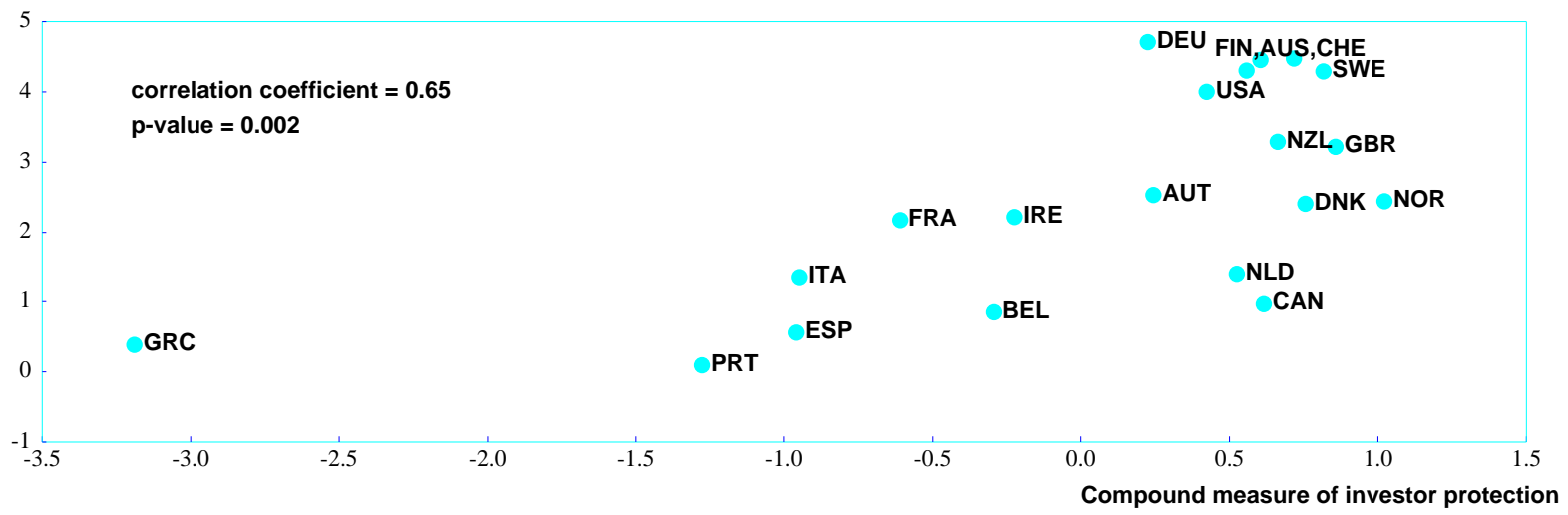

Note: The measure of investor protection is the first principal component of legal enforcement, transparency, shareholder and creditor rights' variables as described in the text. Re-estimation without data for Greece yields correlation coefficents of $0.44,0.47$ and 0.62 with p-values of $0.050,0.042$, and 0.005 , respectively, for the variables listed above.

* : Excluding Japan.

Source: OECD. 
Figure 2 : Investments in innovative activity and investor protection

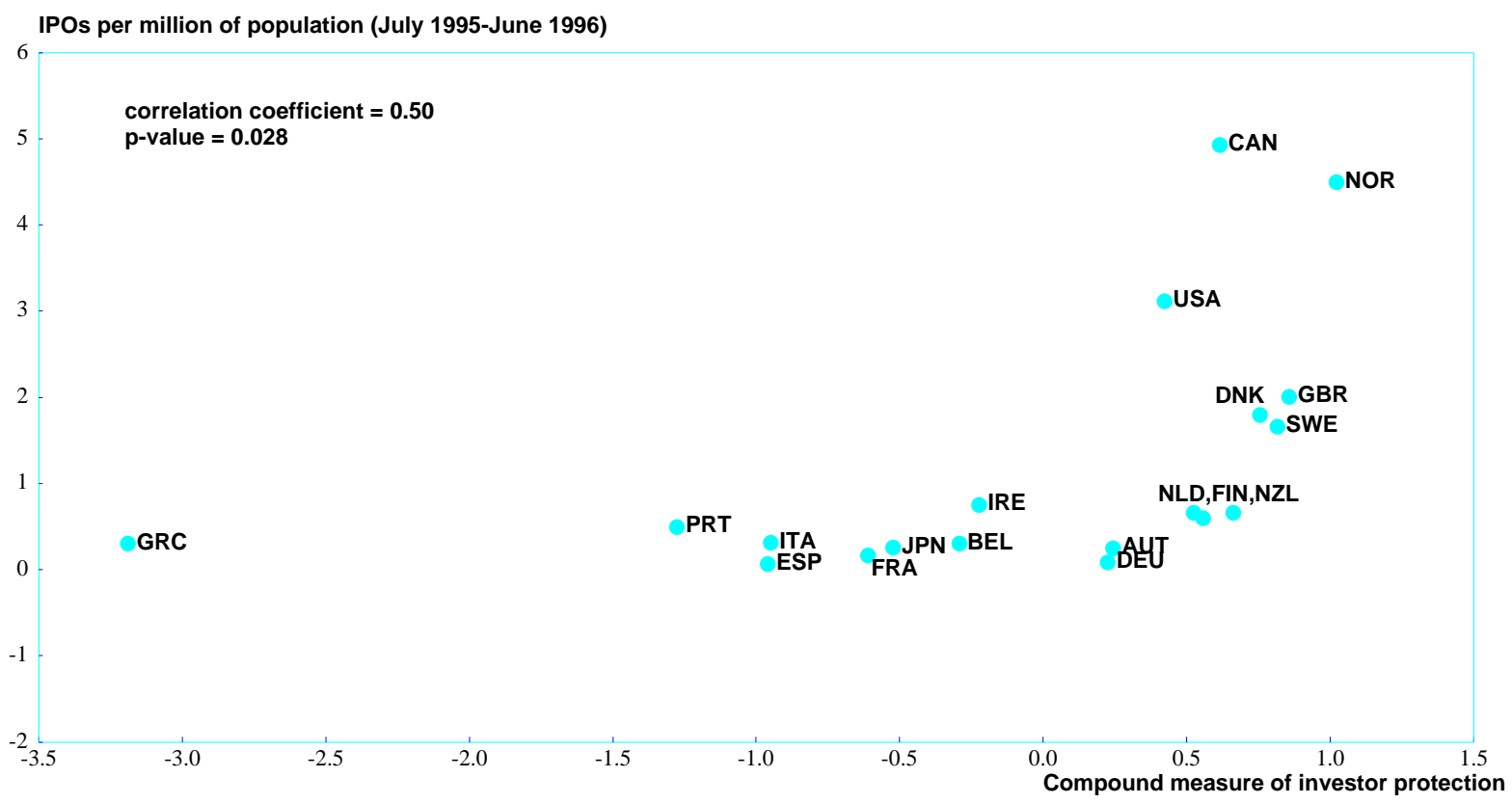

Venture capital investment, early stage and expansion, in per cent of GDP (average 1995-1998) *

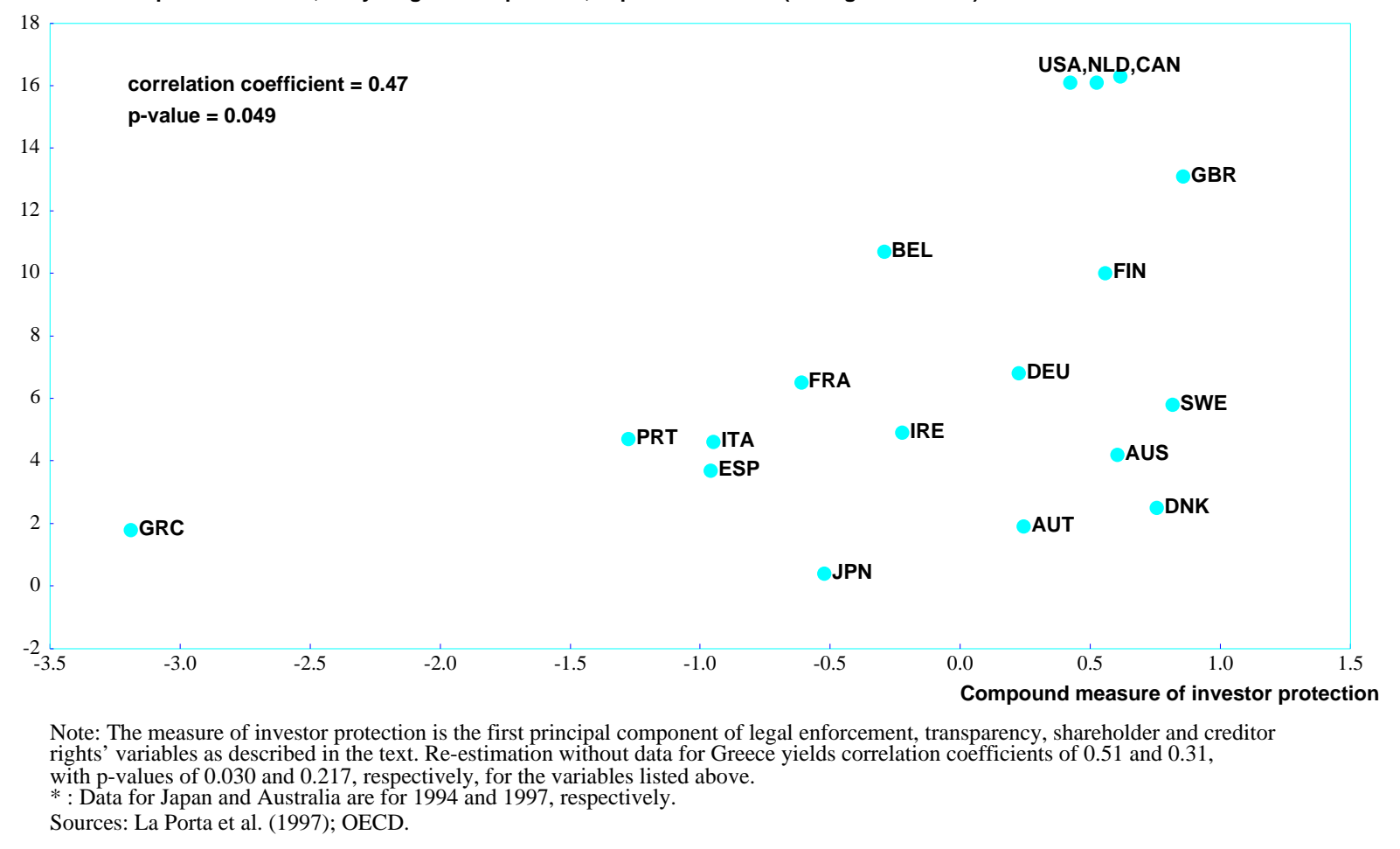


Figure 3. : Liquid liabilities to GDP
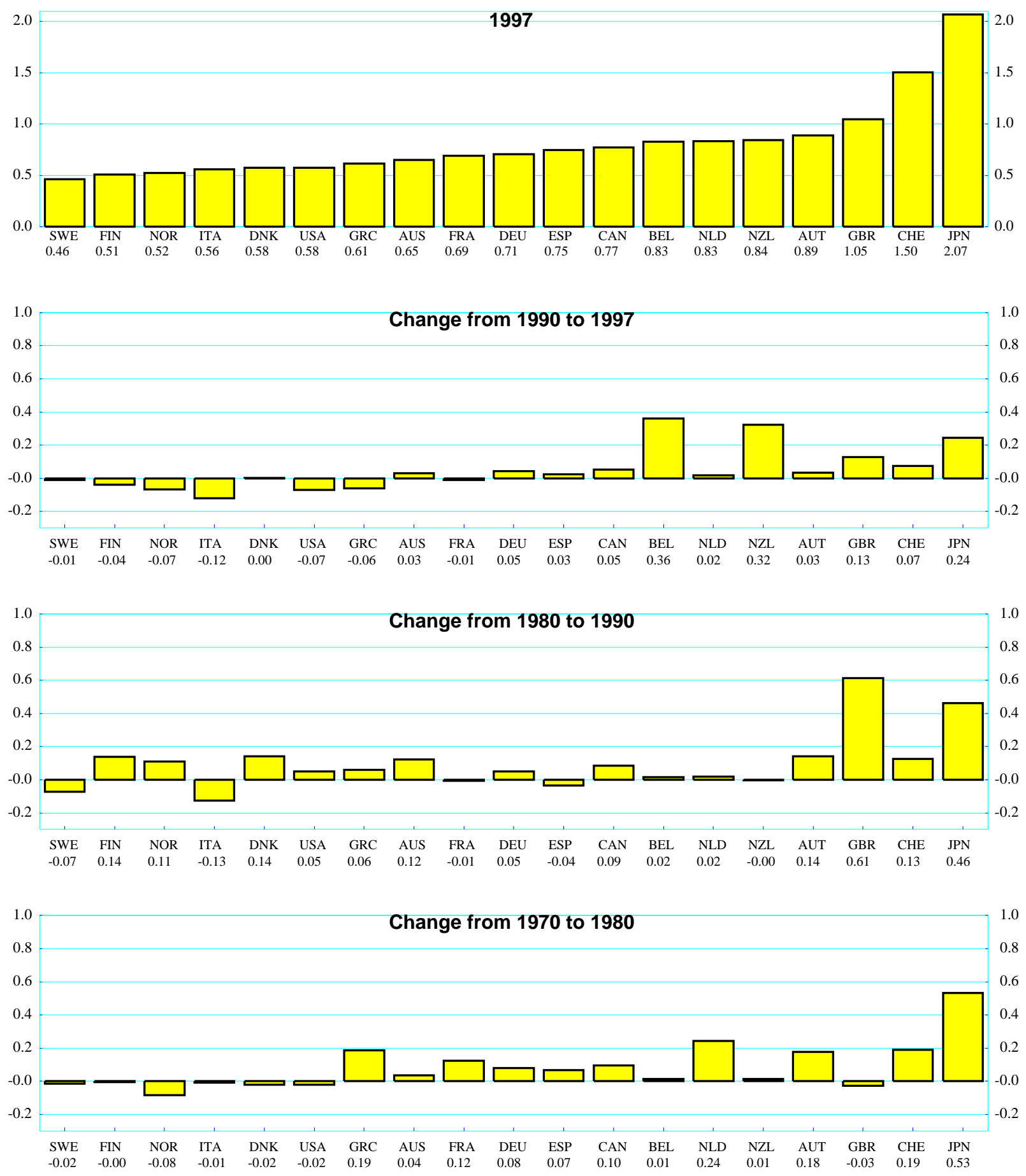

Source : World Bank. 
Figure 4 : Private credit by deposit money banks to GDP
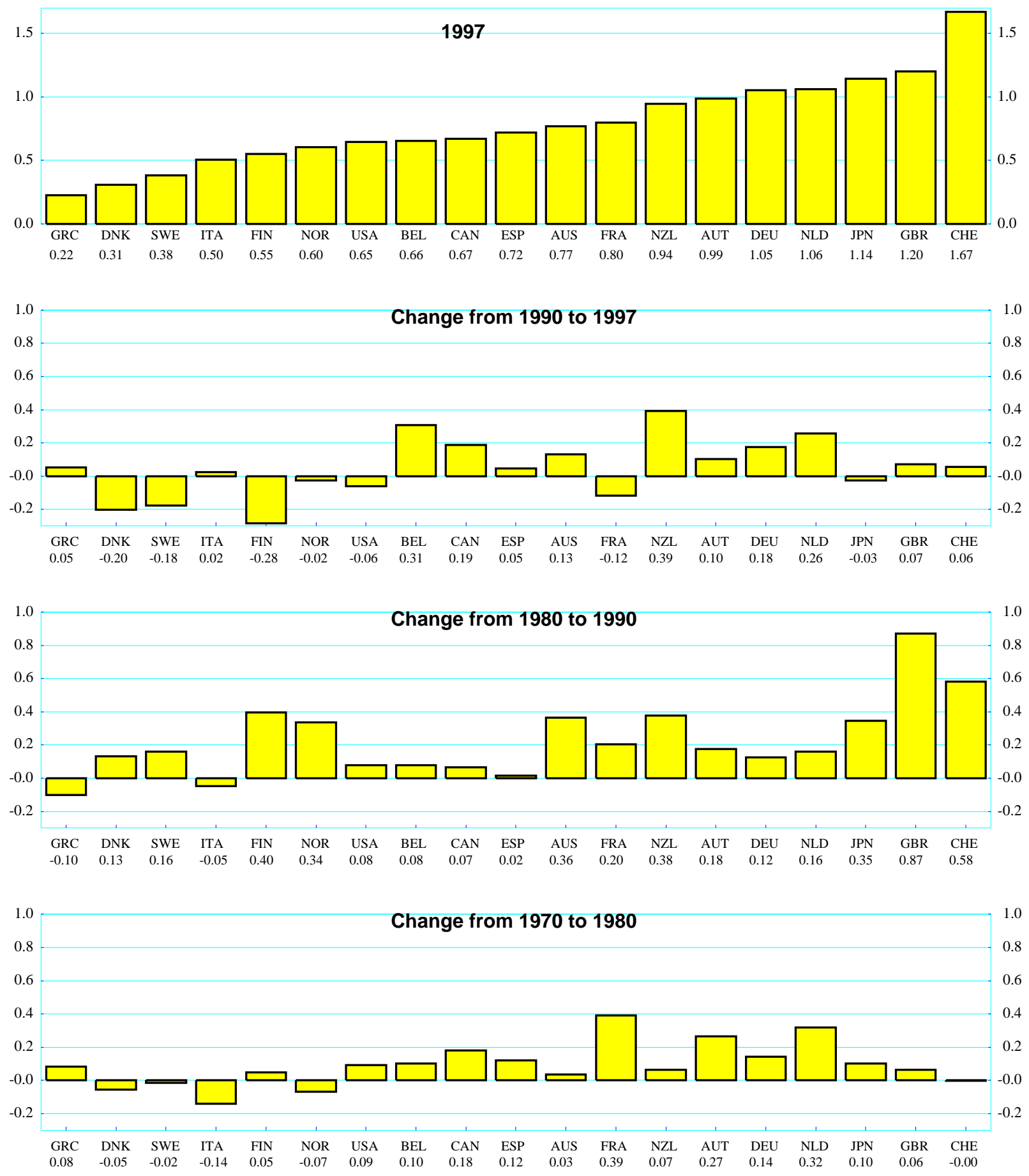

Source : World Bank. 
Figure 5. : Stock market capitalisation to GDP
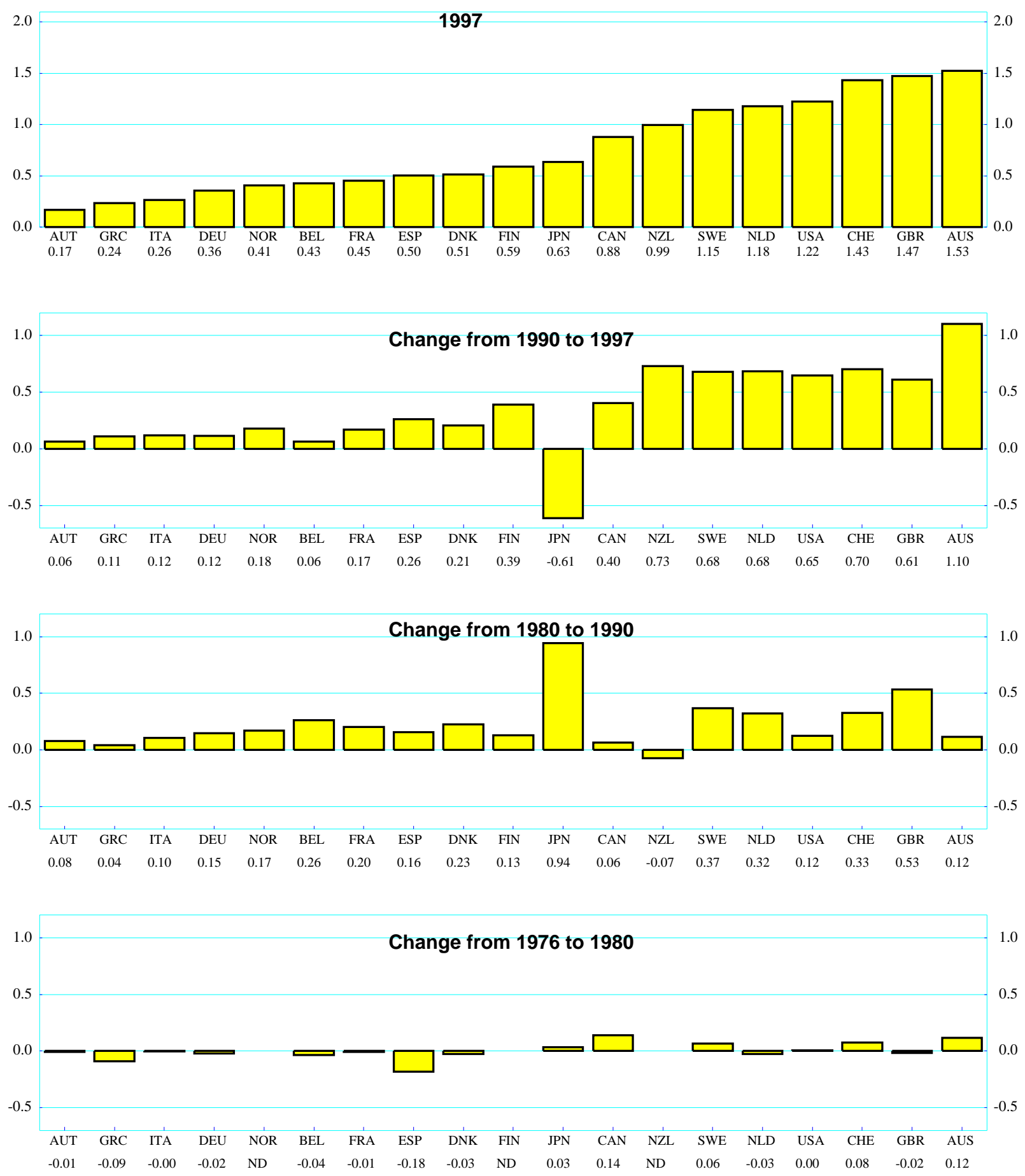

Note : Latest year available for Belgium and Switzerland is 1996.

First year available for New Zealand is 1985, for Finland 1983, and for Norway 1981.

Source : World Bank. 
Figure 6 : Financial development and framework conditions : private credit and stock market capitalisation

Private credit by deposit money banks to GDP (average 1990-1997)
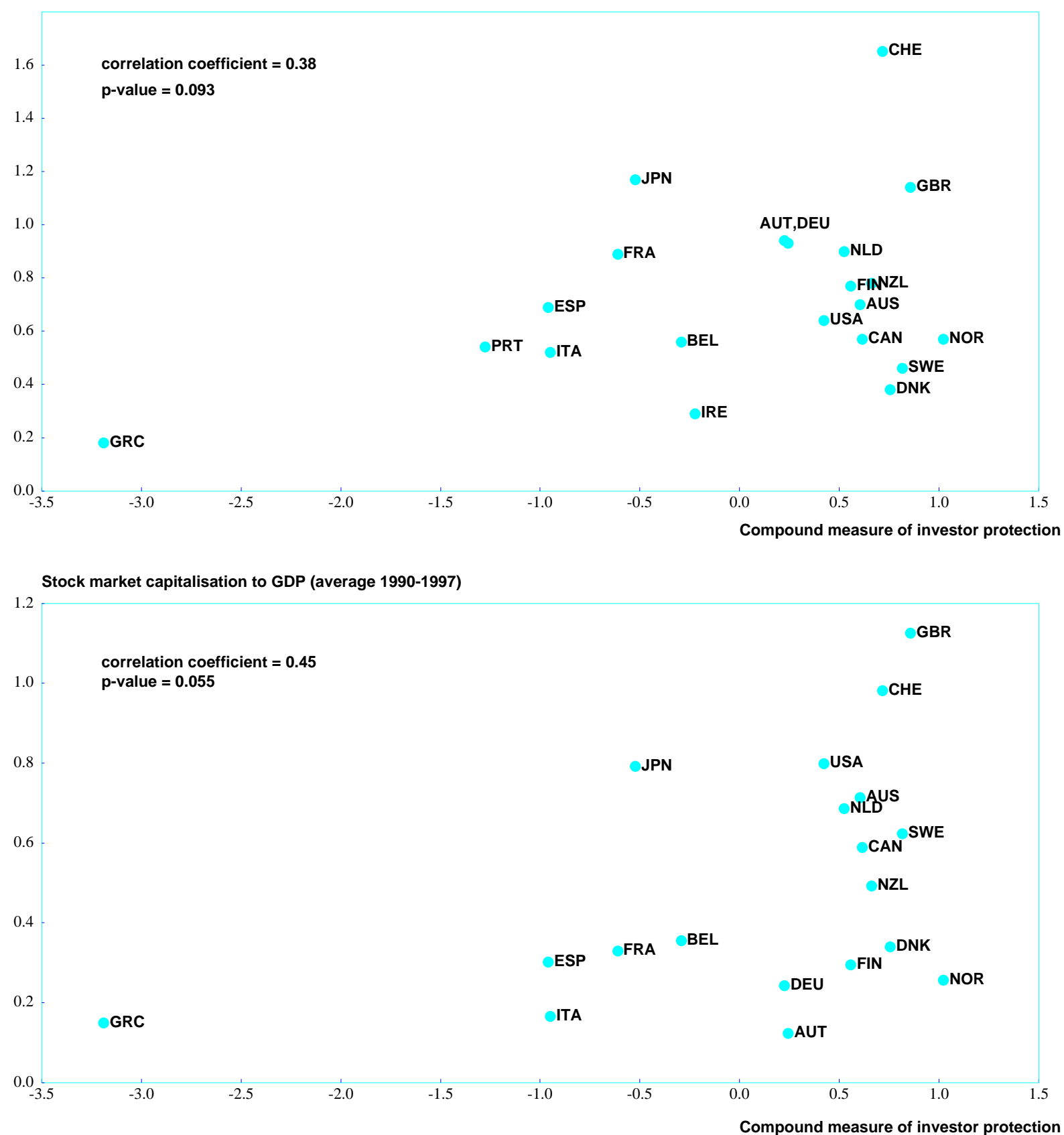

Note : The measure of investor protection is the first principal component of legal enforcement, transparency, shareholder and creditor rights' variables as described in the text. Re-stimation without data for Greece yields correlation coefficients of 0.28 and 0.55 , with p-values of 0.233 and 0.019 respectively, for the variables listed above. Sources: OECD; World Bank. 
Figure 7. Real private non-residential fixed capital formation

Average growth from 1990 to 1997
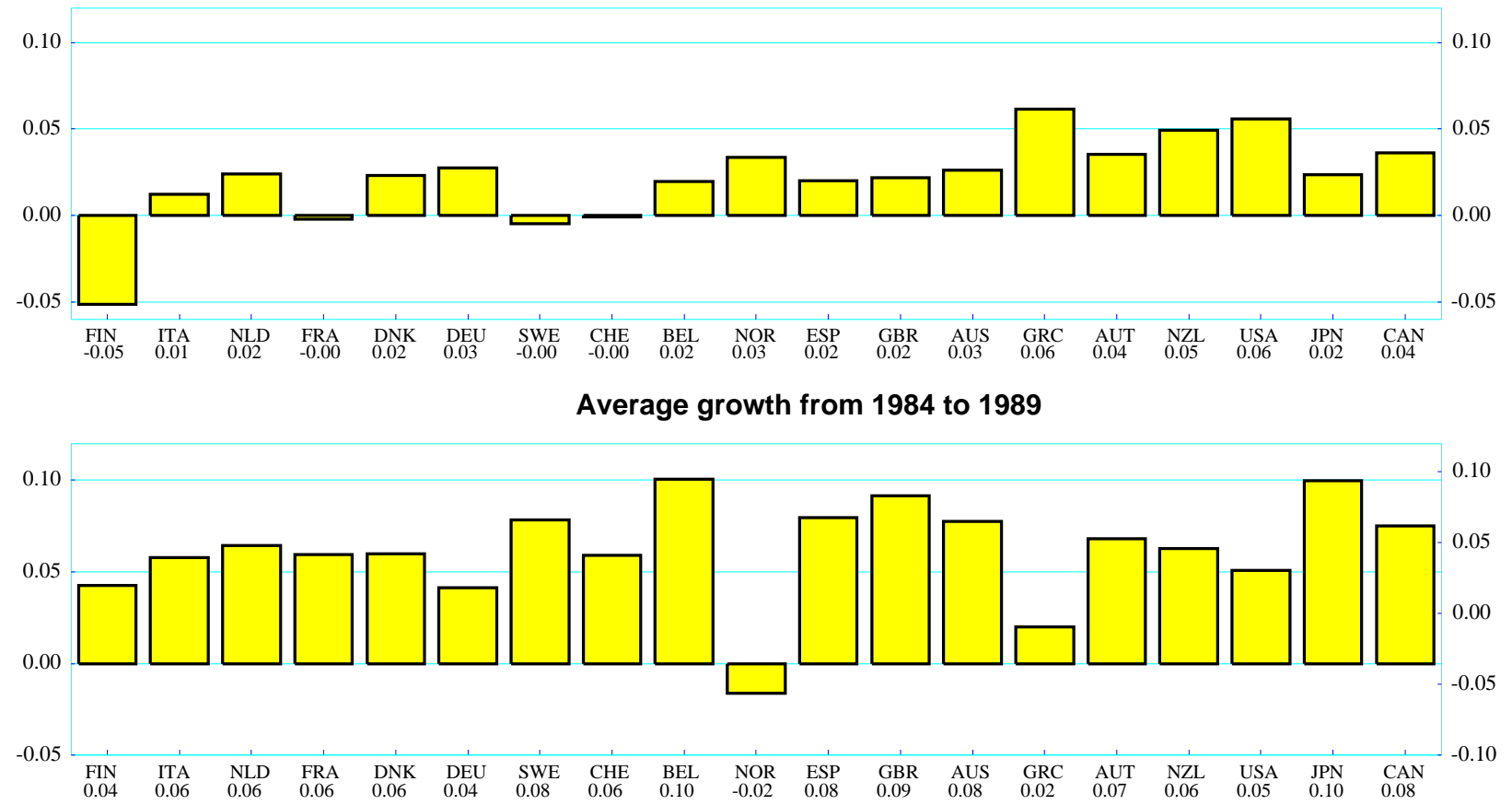

Average growth from 1980 to 1983

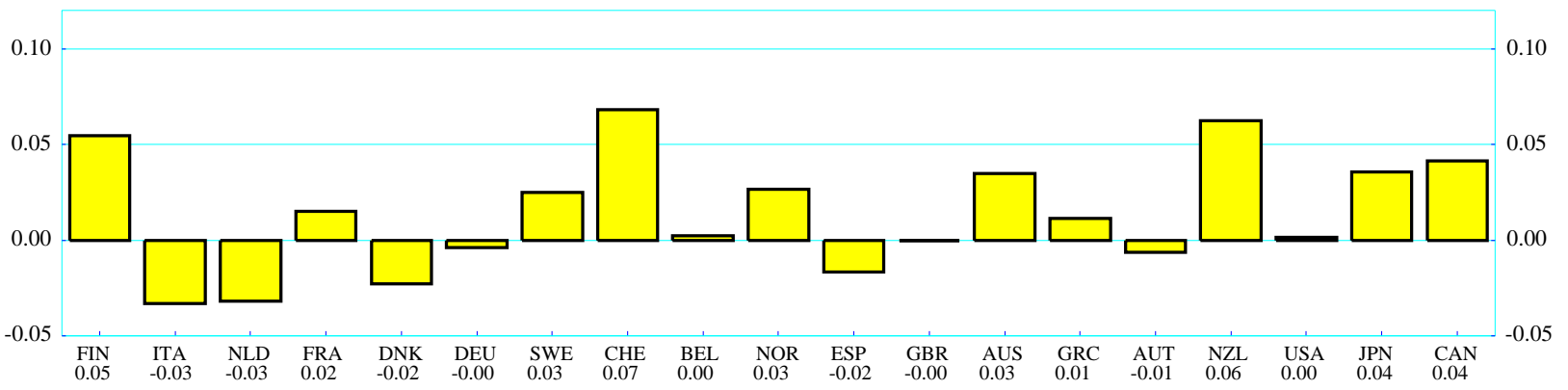

Average growth from 1970 to 1979

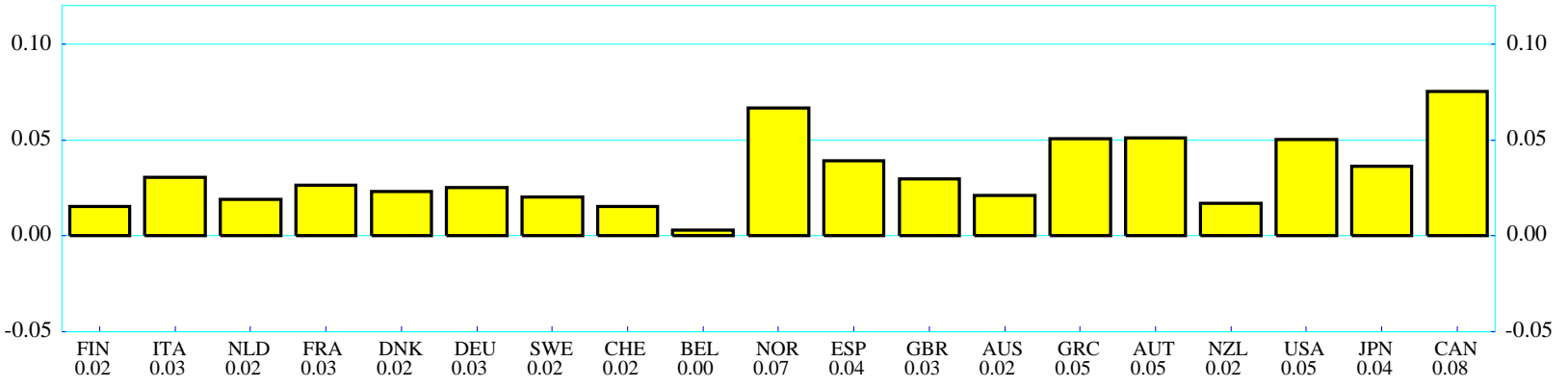

Source : OECD. 
Figure 8: Coefficient estimates for different samples

\section{Liquid liabilities}

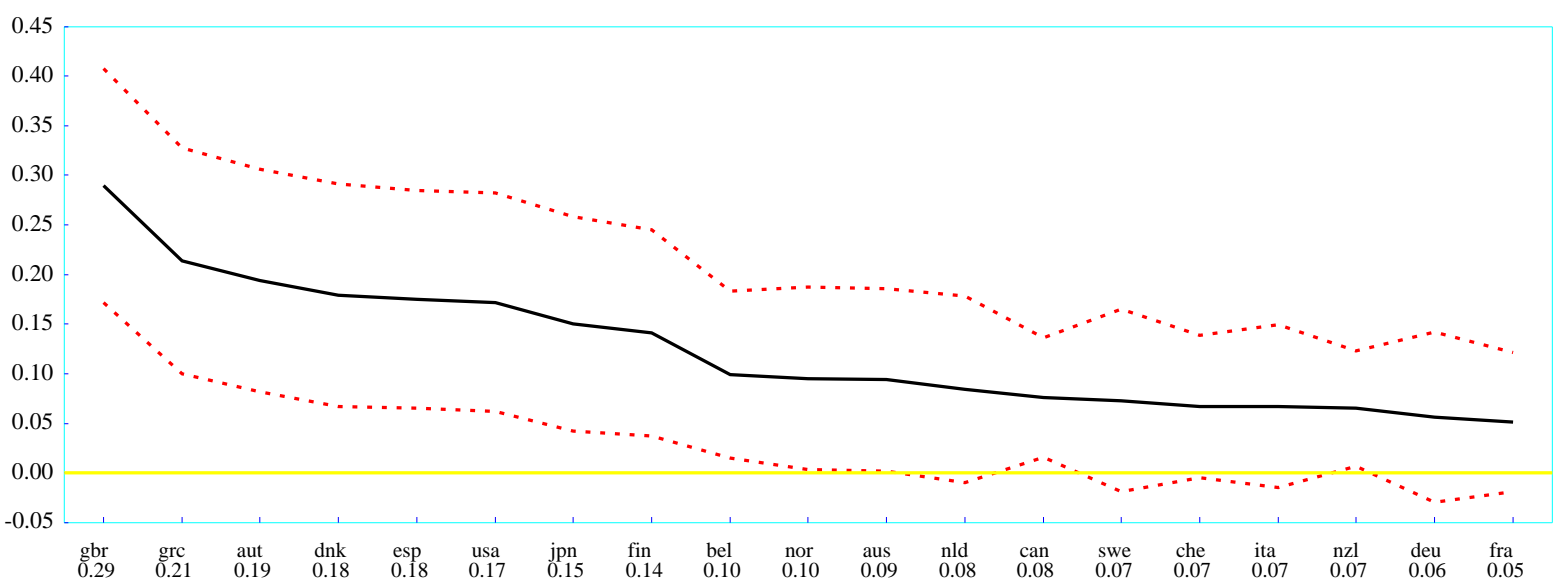

Private credit of deposit money banks

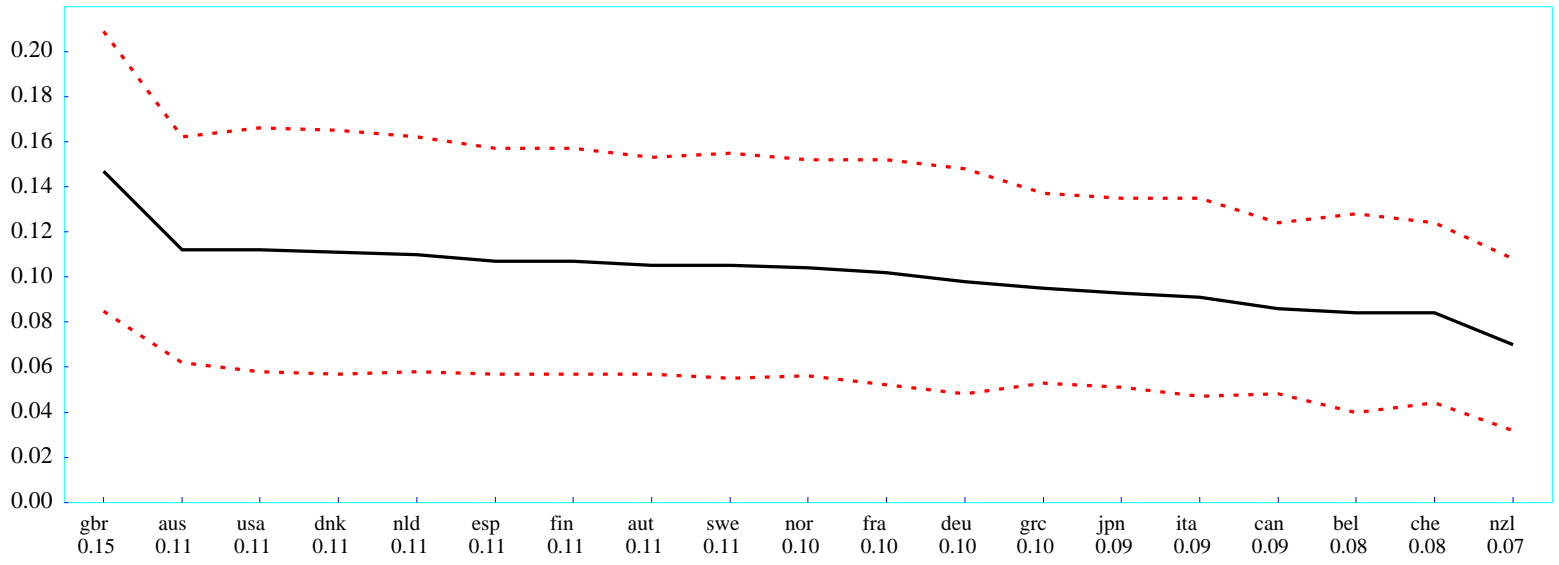

Stock market capitalisation

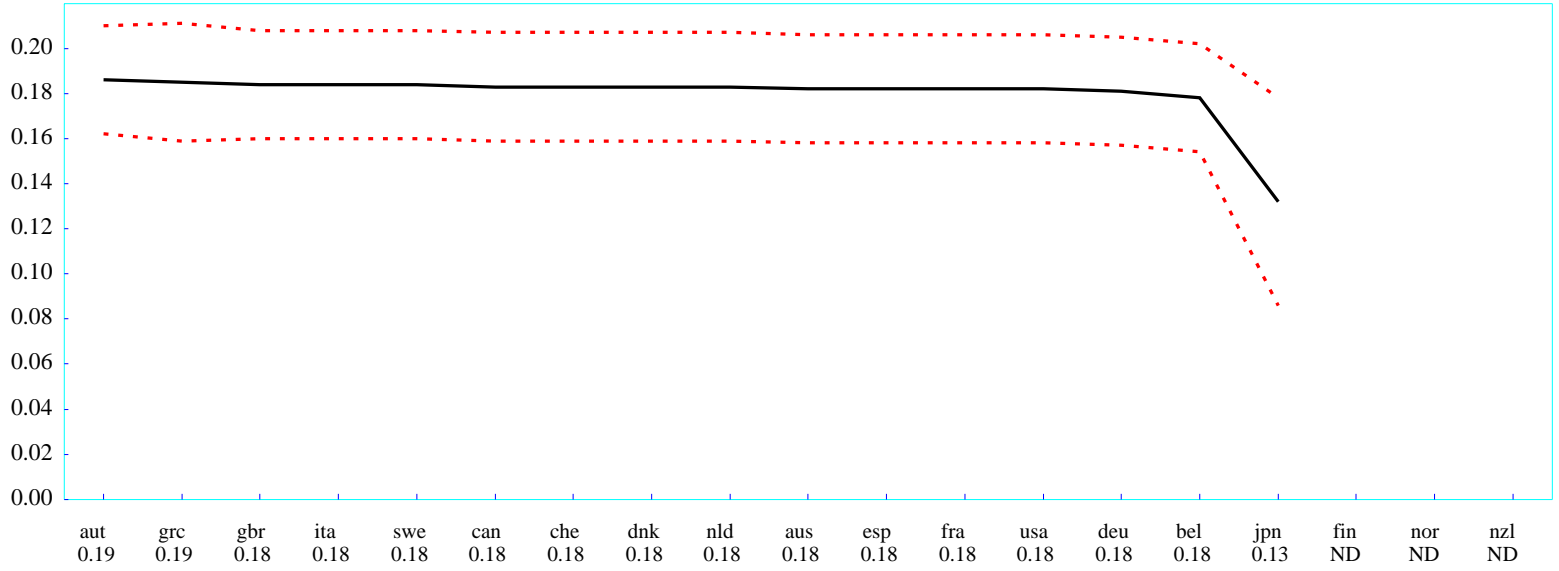

Note : Coefficient estimates and standard error bands according to PMG (95\% confidence interval around coefficient estimate) when excluding one country at a time from the sample. The coefficient estimates are arranged in decreasing order. 
Figure 9 : Coefficient estimates for different time periods

\section{Private credit of deposit money banks}
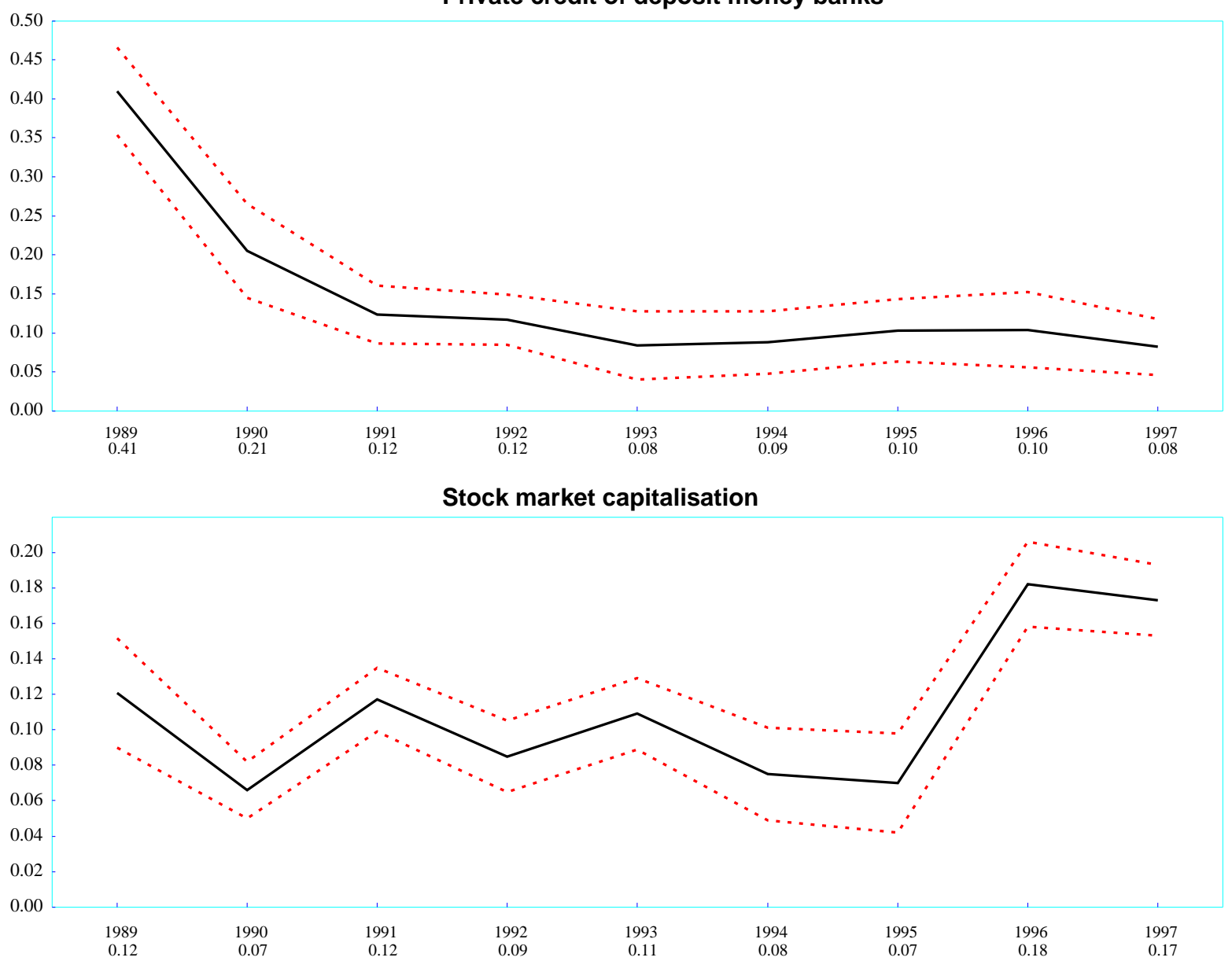

Note : Coefficient estimates and standard error bands according to pooled mean group estimates (95\% confidence interval around coefficient estimate) when shortening the sample to finish in year shown. The lag length is chosen according to the Schwarz Bayesian criterion, where the maximum lag is set equal to two (one in the case of the regression on stock market capitalisation from 1976 to 1989). Note that the estimates in the two panels are not strictly comparable as the begining dates for the samples differ. 


\section{ECONOMICS DEPARTMENT \\ WORKING PAPERS}

279. House Prices and Economic Activity

(January 2001) Nathalie Girouard and Sveinbjörn Blöndal

278. Encouraging Environmentally Sustainable Growth in the United States (January 2001) Paul O’Brien

277. Encouraging Environmentally Sustainable Growth in Denmark (January 2001) Paul O’Brien and Jens Høj

276. Making Growth more Environmentally Sustainable in Germany (January 2001) Grant Kirkpatrick, Gernot Klepper and Robert Price

275. Central Control of Regional Budgets : Theory with Applications to Russia (January 2001) John M. Litwack

274. A Post-Mortem on Economic Outlook Projections (December 2000) Vassiliki Koutsogeorgopoulou

273. Fixed Cost, Imperfect Competition and Bias in Technology Measurement: Japan and the United States (December 2000) Kiyohiko G. Nishimura and Masato Shirai

272. Entry, Exit, and Aggregate Productivity Growth: Micro Evidence on Korean Manufacturing (December 2000) Chin-Hee Hahn

271. The Tax System in Korea: More Fairness and Less Complexity Required (December 2000) Thomas Dalsgaard

270. A Multi-Gas Assessment of the Kyoto Protocol (October 2000) Jean-Marc Burniaux

269. The Changing Health System in France (October 2000) Yukata Imai, Stéphane Jacobzone and Patrick Lenain

268. Inward Investment and Technical Progress in the UK Manufacturing Sector (October 2000) Florence Hubert and Nigel Pain

267. Aggregate Growth: What have we Learned from Microeconomic Evidence? (October 2000) John Haltiwanger

266. Determinants of Long-term Growth: A Bayesian Averaging of Classical Estimates (BACE) Approach (October 2000) Gernot Doppelhofer, Ronald I. Miller and Xavier Sala-i-Martin

265. The Great Reversals: The Politics of Financial Development in the $20^{\text {th }}$ Century (October 2000) Raghuram G. Rajan and Luigi Zingales

264. Trade and Growth: Still Disagreement about the Relationship (October 2000) Robert Baldwin

263. Growth Effects of Education and Social Capital in the OECD Countries (October) Jonathan Temple 
262. Human Capital in Growth Regressions: How Much Difference Does Data Quality Make? (October 2000) Angel de la Fuente and Rafael Doménech

261. Raising the Speed Limit: US Economic Growth in the Information Age (October 2000) Dale W. Jorgenson and Kevin J. Stiroh

260. Summary of an Informal Workshop on the Causes of Economic Growth (October 2000) Jonathan Temple

259. Knowledge, Technology and Economic Growth: Recent Evidence from OECD Countries (October 2000) Andrea Bassanini, Stefano Scarpetta and Ignazio Visco

258. Average Effective Tax Rates on Capital, Labour and Consumption (October 2000) David Carey and Harry Tchilinguirian

257. The Health Care System in Poland (September 2000) Nathalie Girouard and Yutaka Imai

256. Public Expenditure Reform: The Health Care Sector in the United Kingdom (August 2000) Vincent Koen

255. Regulatory Reform in Road Freight and Retail Distribution (August 2000) Olivier Boylaud

254. Regulation, Market Structure and Performance in Air Passenger Transportation (August 2000) Rauf Gonenc and Giuseppe Nicoletti

253. Policy Interdependence during Economic Transition: the Case of Slovakia 1999-2000 (June 2000) Joaquim Oliveira Martins and Tristan Price

252. E-Commerce: Impacts and Policy Challenges (June 2000) Jonathan Coppel

251. The Implementation and the Effects of Regulatory Reform: Past Experience and Current Issues (June 2000) Rauf Gonenc, Maria Maher and Giuseppe Nicoletti

250. The Concept, Policy Use and Measurement of Structural Unemployment: Estimating a Time Varying NAIRU across 21 OECD Countries

(June 2000) Pete Richardson, Laurence Boone, Claude Giorno, Mara Meacci, David Rae and David Turner

249. Options for Reforming the Spanish Tax System

(June 2000) Isabelle Joumard and Aristomène Varoudakis

248. Economic Growth in the OECD Area: Recent Trends at the Aggregate and Sectoral Level (June 2000) Stefano Scarpetta, Andrea Bassanini, Dirk Pilat and Paul Schreyer

247. Economic Effects on the 1999 Turkish Earthquakes: an Interim Report (June 2000) Alexandra Bibbee, Rauf Gonenc, Scott Jacobs, Josef Konvitz and Robert Price

246. Policy Influences on Economic Growth in OECD Countries: an Evaluation of the Evidence (June 2000) Sanghoon Ahn and Philip Hemmings

245. The Tax System in the Czech Republic (May 2000) Chiara Bronchi and Andrew Burns 